\title{
ULTRASTRUCTURAL FEATURES OF BLASTOCYST ATTACHMENT AND TROPHOBLASTIC INVASION IN THE RAT
}

\author{
SUMIE TACHI,* G. TACHI* AND H. R. LINDNER \\ Department of Biodynamics, The Weizmann Institute of Science, Rehovot, Israel
}

(Received 11th November 1968, revised 10th March 1969)

Summary. Morphological features of the interaction between the implanting blastocyst and the uterine endometrium were studied by electron microscopy, using material fixed in situ. The observations extended from the pre-attachment stage to the completion of trophoblastic erosion of the uterine epithelium and early decidual transformation of the stromal cells.

After shedding of the zona pellucida, the blastocyst establishes contact with the tips of microvilli and with bleb-like cytoplasmic protrusions of the epithelial cells. Attachment occurred during the afternoon of the 5 th day post coitum (p.c.). Patches of 'bristle-coated' membrane appeared on the trophoblast membrane at that time. A lattice-like substructure was discernible in the cytoplasmic plaques, which are abundant in the early blastocyst. Sperm-tail inclusions were observed in both trophoblast and inner cell mass as late as Day 5 p.c.

By the 6th day p.c., the epithelial microvilli were usually lost and the trophoblast membrane interlocked with that of the epithelial cells, with frequent formation of tight junctions. Leucocytes were occasionally seen in the epithelial layer at the attachment site. Unusually electron-dense cells were often found wedged between the trophoblast and epithelial cells; their possible relation to Wilson bodies is discussed.

The earliest morphological response of the stromal cells to blastocyst attachment was the appearance of changes in nuclear shape, chromatin distribution and nucleolar structure in the subepithelial layer. The deeper subepithelial stroma became oedematous, and diapedesis, erythro-phagocytosis and later the formation of sinusoids could be observed.

During Day 7 p.c., the basement membrane generally disappeared and the trophoblast cells were then in close contact with stromal cells: the distance between the two unit membranes was in the range 100 to $200 \AA$. A 'periplacental fibrinoid barrier' could not be recognized at this stage, but the existence, or later development, of such an immunological barrier could not be excluded.

\footnotetext{
* In partial fulfilment of the requirement for the Ph.D. degree at the Weizmann Institute's Graduate School.
} 
Stromal cells undergoing decidual transformation showed an abundance of membrane-bound ribosomes and a striking accumulation of fibrils, 80 to $90 \AA$ in diameter, displacing the cytoplasmic organelles.

The development of Reichert's membrane was traced from its first appearance as an amorphous deposit along the inner wall of the trophoblast on Day 6 p.c., to the formation of a stratified, membranous structure on the 8th day.

\section{INTRODUCTION}

The mammalian blastocyst exists as a free-floating organism in an aqueous environment before it implants in the maternal endometrium, a process essential for further development of the embryo. Uterine attachment and invasion by the blastocyst is attended, or even preceded, by cellular changes in the endometrial stroma which ultimately result in the formation of the decidua. All these processes are under hormonal control.

Though more than a decade has passed since electron microscopy became a practical tool in biology, ultrastructural information on the early stages of ovum implantation has only recently become available. Larsen (1961) applied this technique to the study of ovum implantation in the rabbit, and Enders (1964) in the armadillo. While the present study was in progress, electronmicroscopic observations were reported on ovum implantation in the mouse (Potts, 1966, 1968; Reinius, 1967; Nilsson, 1967) and in the rat (Enders \& Schlafke, 1967; Nilsson, 1967). Many details of the natural history of this important process are yet to be filled in, and others are in need of confirmation.

This paper presents a description of the ultrastructural changes taking place in the ovum and endometrium from the earliest period of blastocyst attachment to the initial stages of trophoblastic invasion and nidus formation. Particular attention will be paid to the process of trophoblastic invasion and to the origin and development of Reichert's membrane, aspects which have not been covered extensively by the foregoing authors. A summary of this work has been presented at a Workshop on Ovum Implantation held at the Department of Biodynamics of the Weizmann Institute, Rehovot, in August 1967 (Proceedings in press).

\section{MATERIALS AND METHODS}

\section{Animal preparation and terminology}

The animals used were adult female rats, approximately 100 days of age, from the Biodynamics Institute's Wistar-derived colony. They were kept under controlled temperature (22 to $24^{\circ} \mathrm{C}$ ) and cycles of $14 \mathrm{hr}$ illumination per day throughout their life. Vaginal smears were examined daily and recorded. On pro-oestrus, the female rats were caged with adult males. The subsequent day, when spermatozoa were found in the smears, was designated Day 1 of pregnancy or Day 1 post coitum (p.c.). Animals were killed for examination at the following stages of pregnancy: Day 5 at 11.00, 14.00, 20.00, 22.00 and 24.00 hours; Day 6 at $03.00,12.00$ and 24.00 hours; Day 7 at 12.00 hours; Day 8 at 14.00 hours. Two or three animals were used for each experiment. 
The period of incipient pregnancy under study was roughly subdivided into the following stages: pre-attachment stage (morning of Day 5), attachment stage (Day 5 afternoon to Day 6 midnight), and invasion stage (midnight of Day 6 to Day 7). The morphological basis for this terminology will be discussed in the subsequent sections of this paper.

\section{Fixation of tissues}

The animals were anaesthetized with ether. The ventral aorta was quickly exposed and clamped close to the diaphragm. A small polyethylene catheter was rapidly introduced distal to the clamp, and warm $3 \%$ glutaraldehyde solution buffered at $\mathrm{pH} 7 \cdot 2$ with cacodylate-HCl (Sabatini, Bensch \& Barrnett, 1963) was infused slowly into the aorta. The vena cava was incised, and about $50 \mathrm{ml}$ of the fixative perfused from the aorta at an approximate rate of $10 \mathrm{ml} /$ min. Fixation was regarded as satisfactory if the uteri were seen to turn yellow and become firm within a minute. Only adequately perfused specimens were used. The fixed uteri were excised and sliced transversely with stainless steel razor blades into thin segments (about $0.5 \mathrm{~mm}$, or less, thick). These tissue pieces were post-fixed with $1 \%$ osmium tetroxide in phosphate buffer at $\mathrm{pH} 7.2$ (Millonig, 1961) for $2 \mathrm{hr}$.

\section{Electron microscopy}

After passing through an ethyl alcohol series, each tissue piece was carefully sectioned with razor blades under a dissecting microscope into thinner slices while immersed in absolute alcohol. The blastocysts can be recognized as light brownish spots in the uterine lumen.

The required specimens were picked up and embedded in Swiss Araldite resin (Durcupan ACM). Thin sections were cut serially on a Danon ultramicrotome (Yeda Company, Rehovot) and mounted on copper grids. Thick sections for survey purposes were obtained after every third or fourth grid and stained with toluidine blue for light microscopy (Meek, 1963). Thin sections were stained with lead hydroxide in aqueous solution (Karnovsky, 1961).

Observations were done with an RGA EMU 2A or JEM 7 electron microscope operated at the acceleration voltage of $50 \mathrm{kv}$ or $80 \mathrm{kv}$, respectively.

\section{OBSERVATIONS}

\section{INTERACTION BETWEEN BLASTOCYST AND ENDOMETRIUM}

In this section, observations on the mode of contact between the blastocyst and the endometrium are discussed. The description is limited to the direct interaction between these two components, and the pertinent general structural features of each. A more detailed account of ultrastructural changes in the conceptus and endometrium is given in the subsequent sections.

\section{Pre-attachment stage}

Blastocysts observed in utero during this period are surrounded by the zona pellucida, which is moderately electron-dense and composed of fine interlaced 
filamentous elements. Dark granular bodies are commonly found in the zona. The blastocysts at this stage are probably free-floating in the lumen or tenuously adherent to the uterine epithelium (Pl. 1, Fig. 1). Both the trophoblast and the embryonic cells contain abundant 'plaques' (Enders \& Schlafke, 1967; Schlafke \& Enders, 1967), except the peri-nuclear regions where intracellular organelles such as mitochondria, Golgi apparatus and ribosomes are densely distributed. Numerous nuclear pores are seen on the nuclear membrane (Pl. 1, Fig. 1).

Near the luminal surface of the epithelial cells, clear vacuoles are abundantly seen. They are also present in the epithelial cells in much later stages, although they become less numerous as nidation proceeds.

\section{Early attachment stage}

In the authors' rat colony, the blastocyst completed its attachment to the uterine epithelium during the afternoon of Day 5 of pregnancy. Although wide variations in the developmental stages of the ova were observed in specimens obtained at the same time-interval after conception or even from the same horn, by 15.00 hours on Day 5 , most of the ova had reached the blastocyst stage and had lost the zona pellucida (cf. Kraicer, 1967). Attachment of blastocysts to the uterine epithelium might start around noon and almost all of them completed their attachment in the late afternoon of Day 5.

Because of the wide variation in the stage of ovum development or of implantation attained at any one time, the times given in parentheses for each stage of the implantation in the Materials and Methods section must be regarded as approximations, and some overlapping of these stages was observed in practice.

Plate 2, Fig. 2 presents a survey picture of an early attachment site, taken at low magnification. The blastocyst is seen attached to the uterine epithelium at a few points. The striking adaptation of the contour of the uterine surface to the trophoblast surface, even where the two are not in direct contact, suggests that they had already established attachment and that the separation is a fixation artifact. The microvilli of the uterine epithelium are short, and bleblike structures formed by the epithelial cells, analogous to those described by Nilsson (1966b), are seen attached to the blastocyst (cf. Pl. 1, Fig. 3a, b).

Another example of an early attachment site is shown in Pl. 1, Fig. $3 \mathrm{~b}$. Though the material was obtained at 14.00 hours on Day 5 of pregnancy, that is earlier than that shown in Pl. 2, Fig. 2, attachment appears to have advanced beyond the phase shown in Fig. 2. The luminal ends of the epithelial cells are dome-shaped; microvilli are generally present on the epithelial cells, though in some areas they have been lost. In places, particularly where the trophoblast cells are close to the tip of microvilli of epithelial cells, patches of the trophoblast cell membrane appeared studded with bristles, resembling the 'bristlecoated membrane' described by Roth \& Porter (1964) in mosquito oocytes (Pl. 3, Fig. 4). These patches of specialized membrane were first recognized in the specimen obtained around 14.00 hours on Day 5 , and were persistently found in the trophoblast cells observed thereafter till the onset of invasion.

The earliest attachment probably involves only the tip of the microvilli and the 'bleb-like structure' (Pl. 1, Fig. 3b). Later, microvilli are no longer recog- 
nized; the luminal surface of the epithelial cell now appears ruffled, and contact with the trophoblast has become more extensive.

\section{Late attachment stage}

At this stage, the attachment of the blastocyst to the uterine epithelium is more intimate (Pl. 3, Fig. 5), the trophoblast cells interdigitate with the epithelial cells, and occasionally the trophoblastic cytoplasm entirely surrounds cytoplasmic processes of the uterine epithelium.

Glycogen granules are now abundantly seen in the trophoblast (Pl. 3, Fig. 5). The epithelial cells contain numerous, irregularly shaped, clear vesicles. These are occasionally seen to have fused with a 'coated vesicle' (P1. 3, Fig. 6) similar to those described in other tissues by Bruni \& Porter (1965) and Friend \& Farquhar (1967).

In one instance, a polymorphonuclear leucocyte was observed in direct contact with trophoblast cells (Day 6, noon).

Frequently, extremely darkly stained cells of irregular shape, possibly necrotic, were seen wedged between the trophoblast and the epithelium ( $\mathrm{Pl} .4$, Fig. 7), as recently reported by Finn \& Lawn (1968). Epithelial cells in an earlier stage of degeneration are shown in Pl. 4, Fig. 8: three darkly stained cells are seen that retained most morphological characteristics of epithelial cells, such as the ruffled cell surface and clear vesicles at the luminal tip, nuclei situated towards the basal end of the cells, and location of Golgi apparatus above the nucleus. However, in these darkly stained cells most of the mitochondria appear shrunk and lack well defined cristae.

\section{Invasion stage}

After completion of its attachment to the uterine epithelium, the blastocyst starts to invade the endometrium. Plate 5, Fig. 9 shows a survey picture, taken at noon on Day 7 p.c. of the implantation site at this stage, consisting of part of the embryonic cell mass, trophoblastic cells located in the side-wall of the blastocyst in direct apposition to the basement membrane of the uterine epithelium and stromal cells. Almost all the epithelial cells have vanished, and the remaining ones appear about to be engulfed by the trophoblast (PI. 5, Fig. 9). Trophoblastic invasion in this area, that is along the lateral walls of the blastocyst, precedes invasion at the poles.

The earliest sign of trophoblastic invasion can already be recognized by noon of Day 6 p.c. The cytoplasm of trophoblast cells which constitute the side-wall of the blastocyst, particularly the cytoplasm lying beneath the nucleus, thickens so that the cell becomes V-shaped in cross section. The trophoblastic cytoplasm then insinuates itself between adjacent epithelial cells until it reaches the basement membrane (Pl. 5, Fig. 10; Pl. 6, Fig. 11). Many large inclusion bodies of high electron density were observed in the trophoblast cells at this time (P1. 5, Fig. 10); these may represent engulfed, necrotic, epithelial cells. Often a large vacuole filled with débris is seen adjacent to the dumb-bell shaped nucleus of the trophoblastic cell (Pl. 5, Fig. 10).

The uterine epithelial cells at the invasion site contain large fat droplets, and the clear vesicles normally seen in the apical area are much reduced in 
number (Pl. 5, Fig. 10). Beneath the epithelial cells, between the basement membrane and the stromal cells, thick bundles of fibres resembling collagen fibres are present at this stage (Pl. 5, Fig. 10), occasionally accompanied by flocculent material as described by Enders \& Schlafke (1967). These fibres may, in fact, be reticular fibres, as termed in light microscopy (cf. Lobel, Levy \& Shelesnyak, 1967), since these are indistinguishable under the electron microscope from collagen fibres (Harkness, 1964).

In Pl. 6, Fig. 11, which is derived from the same specimen as survey picture Pl. 5, Fig. 9 taken on Day 7 at noon, abembryonic trophoblast cells are seen wedged between the epithelial cells and their basement membrane. Although the basement membrane is detached from the underlying layer of the stromal cells and much ruffled, it appears to be well preserved morphologically, but in several areas near the side walls of the blastocyst, where invasion usually starts, the basement membrane had disappeared by noon of Day 7 p.c.

Various stages of phagocytosis of epithelial cells by the trophoblastic cells were observed (Pl. 5, Fig. 9; Pl. 7, Figs. 13, 14). At the stage seen in Pl. 5, Fig. 9 most of the uterine basement membrane has been denuded of epithelial cells. The only remaining three epithelial cells, and one darkly stained cell, are almost surrounded by trophoblastic cells and their cytoplasmic processes. These epithelial cells are still in good morphological condition and have microvilli on their luminal surface.

Plate 7, Figs. 13 and 14 show phagocytized epithelial cells within trophoblast cells. Mitochondria and fat droplets are still recognizable in the phagocytized cell. The cavity situated at the centre of the cell might be derived from a multi-vesicular body. In the trophoblastic cytoplasm, near the phagocytized cell, a lysosome-like body is observed. Plate 7, Fig. 14 shows another part of the cell shown in Fig. 13. Here, a second engulfed epithelial cell is seen to be disintegrating. The nuclear and cytoplasmic regions are vaguely recognizable.

In the early invasion stage, erythrocytes occasionally escape from endometrial capillaries below the primary decidual zone and are seen in the intercellular spaces (PI. 8, Fig. 15a). Plate 8, Fig. 15b shows erythrocytes within binucleated stromal cells in the peripheral area of a primary decidual zone; one of the phagocytized erythrocytes was in an advanced state of decomposition. The nature of the phagocytic stromal cell is uncertain; one is seen to bear two 'solitary' cilia (cf. Tachi, Tachi \& Lindner, 1969), and neither resembles a macrophage.

\section{Trophoblast-stroma relationship}

It is of some interest to know whether the trophoblast cells establish direct contact with the stromal cells of the uterus during implantation, or whether fibrinoid material secreted by the trophoblast cells intervenes. The latter possibility is suggested by the findings of Kirby, Billington, Bradbury \& Goldstein (1964), and Bradbury, Billington \& Kirby (1965), who demonstrated the presence of such material in later stages of pregnancy in the mouse. During the early stage of invasion (Day 7 p.c.), the basement membrane of the epithelium is left intact, separating the trophoblast from the stromal cells, but as invasion proceeds, the basement membrane becomes unrecognizable. In Pl. 6, Fig. 12a, b, 
trophoblast cells obtained on Day 6, midnight, and Day 8, afternoon, are seen in direct contact with an epithelial cell and a stromal cell respectively, without any membranous structure between them. It was not possible at this stage to demonstrate any 'fibrinoid' material resembling that observed by Kirby et al. (1964) in the mouse, around the implanting blastocyst or the ectoplacental cone. Thus, there appears to be at least a transient phase when no physical barrier between trophoblast and maternal tissues is evident. On the other hand, Reichert's membrane, which is situated at the inner wall of the trophoblast, increases its thickness markedly on Day 8 p.c.

\section{BLASTOCYST}

\section{Blastocyst expansion}

The trophoblast cells have the capacity to expand or to be stretched out to extreme thinness. During the early attachment stage, the trophoblastic cells, spread out in contact with epithelial cells, measure less than half a micron in thickness. In Pl. 9, Fig. 16, the thinnest part is 0.2 to $0.3 \mu$ across. The expanded trophoblast is held together by junctional complexes scattered along the common borders of its component cells (Pl. 1, Fig. 3; Pl. 9, Fig. 16).

\section{Sperm inclusions}

In blastocysts of the pre-implantation stage, supernumerary spermatozoa were observed engulfed in the trophoblast cells (Tachi \& Kraicer, 1967). Similar supernumerary sperm inclusions have now been found in implanting blastocysts. Plate 9, Fig. 17a shows a sperm tail in a trophoblast cell during the early attachment stage. Although the axial filament complex and the peripheral coarse fibres appear degenerate, the tail sheath and longitudinal columns are well preserved. In Pl. 9, Fig. $17 \mathrm{~b}$ to d, a sperm tail is found within the embryonic cell mass, apparently being phagocytized by an embryonic cell. The serial sections presented demonstrate that the sperm tail is partially outside the cell and partially inside it. In the tail fragment, only the peripheral coarse fibres are clearly recognizable, whereas the axial filament complex and the outer sheath are not observed.

\section{Cytoplasmic 'plaques' and organelles}

A large portion of the cytoplasm of both trophoblastic and embryonic cells in the pre-attachment and early attachment stages is occupied by patches of filamentous mesh or 'plaques' (Schlafke \& Enders, 1967), which give a translucent appearance to the cells in low power electron micrographs (Pl. 2, Fig. 2; Pl. 1, Fig. 3). These plaques are unique structures found in the early ova of several mammalian species (Enders \& Schlafke, 1965). They probably consist of parallel plate-like elements (Pl. 10, Fig. 18a), 1 to $2 \mu$ in length and about $170 \mathrm{~m} \mu$ thick, sometimes curved, exhibiting a regularly repeating substructure: sections in the plane of the platelets show dark striations, and, in rare instances, cross striations forming a lattice (PI. 10, Fig. 18b), with intervals of about $400 \AA$ between intersections.

The plaques seem to disappear gradually towards the onset of trophoblastic 
invasion, leaving large electron-sparse areas which may coexist, for a time, with organized plaques in the same cell (Pl. 10, Fig. 18a).

Towards the end of the attachment stage and during invasion, the cytoplasm of both inner cell mass and trophoblastic cells is crowded with free clustered ribosomes. The rough-surfaced endoplasmic reticulum of the differentiating endodermal cell layer forms much dilated cisternae filled with mildly electrondense material (Pl. 10, Fig. 19).

During the invasion stage, lysosome-like bodies were frequently observed, particularly in the trophoblast cells. They are also present in the embryonic cells (Pl. 5, Fig. 9).

\section{Origin and development of Reichert's membrane}

The embryos of rodents and insectivores exhibit a thin, homogeneous, noncellular membrane, which when fully developed covers the entire inner surface of the trophoblastic ectoderm, separating it from the distal (parietal) endoderm (Boyd \& Hamilton, 1952); it stains pink with eosin. This membrane is named after Reichert, who first observed it in the guinea-pig (Reichert, 1862).

In the rat, Reichert's membrane first becomes recognizable on Day 6 of pregnancy with the appearance of an amorphous secretion along the inner wall of the trophoblast (Pl. I1, Fig. 20; Pl. 12, Fig. 22 a to c). Dense granules, 320 to $340 \AA$ in diameter, are seen attached to this secretion. These granules might be dislocated glycogen granules, rather than true secretory products. Some electron micrographs (e.g. Pl. 11, Figs. 20, 21) suggest that endodermal cells which lie in close contact with the trophoblast cells participate in the formation of this membrane: in Fig. 20, a streak of material is seen to stretch from an endodermal cell to the inner wall of the trophoblast.

Towards Day 7 of pregnancy, the layer of amorphous material adhering to the trophoblastic cell membrane becomes more dense, and now resembles a basement membrane (Pl. 12, Fig. 22d). By Day 8, it has become very thick and stratified (Pl. 12, Fig. 22e); the layer which lies immediately on the trophoblastic cell membrane appears more dense compared to the other layers.

Plate 11, Fig. 21 represents part of a dormant blastocyst: the rat was spayed on Day 4 p.c. and given progesterone, so that implantation was delayed. On Day 10, the blastocyst was flushed out of the uterus and fixed with glutaraldehyde and osmium tetroxide. It had lost its zona pellucida; the endodermal cells were differentiated, and devoid of plaques. Reichert's membrane, in this delayed blastocyst, has attained the thickness commonly seen in normally implanting blastocysts on Day 7 or 8 p.c., and is closely adherent to the inner surface of the trophoblast cells, but also extends into pouches formed by endodermal cells.

\section{STROMAL GELLS}

\section{General description}

During the pre-attachment stage, the stromal cells in the subepithelial region have irregularly shaped nuclei with evenly distributed chromatin. Rough surfaced endoplasmic reticulum is sparse, and mostly undilated. 
During the early attachment stage, the deeper subepithelial layers of the stroma become markedly oedematous. The nuclei assume a smoother, more spherical shape (Pl. 13, Fig. 23). They now have prominent and highly granulated nucleoli, often located in close proximity to the nuclear membrane. Multiple nucleoli (two or three) are commonly observed. The nucleolonema appears like tangled thick yarn with high electron density. The rough-surfaced endoplasmic reticulum is branched and distended, and filled with fairly darkly stained material.

In the late attachment stage, chromatin is condensed under the nuclear membrane. Often large rod-shaped nucleoli are observed (Pl. 13, Fig. 24); these are commonly attached to the nuclear membrane. At the same time, the cisternae of the rough-surfaced endoplasmic reticulum tend to form arrays (Pl. 13, Fig. 24). Glycogen granules, which are not conspicuous in the earlier stages, are accumulated during this period and are often seen in association with fat droplets (cf. Enders \& Schlafke, 1967).

Many of the stromal cells carry solitary cilia (Tachi et al., 1969), that is a ciliary shaft associated with the diplosome. Binucleated stromal cells, which are common at this stage, carry two to four such cilia (Tachi et al., 1969).

On Day 7 of pregnancy, when the trophoblast has started to invade the endometrium, the stromal cells are filled with fibrous material (Pl. 5, Fig. 9) which will be considered in detail later. Between the stromal cells, wide lacunae are present into which microvilli project from the surrounding stromal cells. These lacunae may represent early sinusoids, such as are seen in this region in later stages. Indeed, in another specimen (Day 6, midnight; Pl. 14, Fig. 25), a capillary is seen which has lost part of its endothelial lining; the denuded patch shows stromal microvilli protruding into the lumen.

On Day 8, the epithelial lining of the uterus has been completely eliminated at the site of implantation, and the trophoblast cells establish direct contact with the stromal cells. At this stage, marginal chromatin condensation in the stromal cell nuclei has become more conspicuous. The cytoplasm is packed with bundles of fibrillar material (Pl. 14, Fig. 26).

\section{Polyribosomes}

One of the striking phenomena observed in the stromal cells, both of the sub-epithelial and of the mid-stromal region, during the attachment of the blastocyst is the appearance of numerous polyribosomes (Pl. 15, Fig. 27). The polyribosomes are distinctly coil-shaped or U-shaped and consist commonly of ten to fifteen ribosomes. The maximum number of ribosomes observed in a polyribosome was twenty-eight (Pl. 15, Fig. 27, inset).

The polyribosomes seem to be situated at the periphery of the dilated cisternae of the endoplasmic reticulum which contains mildly electron-dense, flocculent material (Pl. 15, Fig. 27). Clusters of polyribosomes are usually seen on a dark-staining background, suggesting that the polyribosomes are related to the endoplasmic reticulum. Groups of polyribosomes are also found localized around the outer nuclear membrane, where an abundant meshwork of fibrillar material is often found (Pl. 15, Fig. 28). 


\section{Fibrillar material}

A characteristic feature of the stromal cells forming the nidus is the presence of thick bundles of fibrillar structure (Enders \& Schlafke, 1967) in their cytoplasm. During the invasion stage, they are so numerous that the other cellular organelles are displaced (Pl. 14, Fig. 26; PI. 16, Fig. 29). A typical fibril is about 80 to $90 \AA$ in thickness and probably about $1 \mu$ or more in length. Cross-sections of these bundles present patches of fine, round dots (Pl. 16, Fig. 29, inset). These fibrils are already recognizable during the early attachment stage, but they are sparse at that time, and chiefly concentrated in the peri-nuclear region and the periphery of the cytoplasm (Pl. 15, Fig. 28).

\section{DISCUSSION}

\section{The implantation chamber}

The observations presented in this paper deal with the ultrastructural features and chronology of the interaction between the blastocyst and endometrium, from the time of fixation of the blastocyst to the uterine wall until completion of the erosion of the uterine epithelium. In such a study the preservation of the natural relationships between the interacting components during preparation of the tissue for microscopic examination is of paramount importance. In light microscopic observations, differences between frozen and fixed material have been noted in the width of the uterine lumen surrounding the blastocyst, the fixed material exhibiting a wider lumen, probably due to shrinkage artifacts (De Feo, 1967; Lobel et al., 1967). In the glutaraldehydeperfused specimens of the present study, the blastocyst is seen enclosed in an implantation chamber formed by epithelial cells in close apposition to the trophoblast cells, from the earliest stage of attachment until the beginning of invasion. This picture is in agreement with observations by Reinius (1967) in the mouse and resembles that obtained with frozen sections in the rat, but differs from descriptions based on material treated with conventional fixatives (cf. Blandau, 1949). Nilsson (1966a) attributed the close application of the uterine epithelium to the blastocyst in rats treated with progesterone and oestrogen (mode of fixation not specified) to adhesiveness of the cell surface induced by the oestrogen treatment.

\section{Mode of blastocyst attachment}

During the early attachment stage, contact between uterine epithelial cells and the trophoblast cells is not extensive: it is confined to the tips of the microvilli and to the bleb-like cytoplasmic protrusions of the epithelial cells. These protrusions were first described by Nilsson (1958) in the mouse and later in the rat (Nilsson, 1966b) and were thought to represent one of the features of the oestrogen-induced differentiation of the uterine epithelium during the pre-attachment phase. Warren \& Enders (1964), on the other hand, suggested that formation of the cytoplasmic protrusions might be part of a secretory mechanism, possibly involved in the release of glycogen-like material from the 
uterine epithelium. The present observations revealed that the bleb-like structures are indeed adherent to the blastocyst during the earliest stage of attachment. However, similar cytoplasmic protrusions also occur at sites not normally involved in blastocyst anchorage, e.g. on the mesometrial side of the uterine lining, and it appears that these structures play no rôle in determining the localization or spacing of implantation sites.

\section{Pre-invasion blastocyst-endometrial relationships}

It is difficult to obtain a general picture of endometrial histology by electron microscopy. Comparisons were therefore made between endometrium beneath a pre-implantation blastocyst still enclosed in its zona pellucida, and the endometrium in the immediate vicinity of an implantation site. While morphological changes in the epithelial cells were not very striking during the early attachment stage (14.00 to 16.00 hours of Day 5 p.c.), the sub-epithelial stromal cells nearest to the implantation site already exhibited recognizable changes in the shape of the nuclei and dispersion of their chromatin. At about that time, or slightly later ( 17.00 to 23.00 hours, Day $\mathrm{L}_{4}$, equivalent to Day 5 p.c.), an increase in nuclear size, thymidine uptake, and increased succinic acid dehydrogenase activity have been observed in these stromal cells by light microscopy, autoradiography or histochemical techniques in this laboratory (Lobel et al., 1967).

The nature of the stimulus which is passed from the blastocyst across the uterine epithelium to evoke the decidual response in the stroma remains uncertain; physical and chemical, as well as immunological factors have been implicated (for reviews see Shelesnyak, 1957; Blandau, 1961; De Feo, 1967; Shelesnyak, Marcus \& Lindner, 1969). The mode in which a hypothetical chemical messenger might be transmitted from the blastocyst to the endometrium is equally unknown. Larsen (1961), working with the rabbit, and Potts (1966, 1968), studying the mouse, both described cytoplasmic fusion between trophoblast and epithelial cells after attachment of the blastocyst. Larsen (1961) argued that the observed fusion was unlikely to be the result of a fixation artifact. In the present observations on the rat, however, conclusive evidence of trophoblast-epithelial cell fusion could not be obtained. Proof of cell fusion by microscopy only is often equivocal, since cell boundaries may appear to vanish where the plane of sectioning is tangential to the cell membrane.

Wilson (1963) described bodies deeply staining with basic dyes and possibly rich in RNA, believed to pass from embryonic cells to the maternal endometrium during the early attachment stage in mice. He named these bodies 'primary invasive cells', but Finn \& McLaren (1967) proposed the provisional name W-bodies, a term devoid of functional or structural implications. Recently, Finn \& Lawn (1968) reported the presence of electron-dense bodies near blastocyst attachment sites in mice. They tentatively interpreted these as degenerative epithelial cells and suggested they might be identical with the W-bodies. Similar electron-dense bodies and degenerating epithelial cells were observed here at blastocyst attachment sites in rats. The present authors' observations favour the conclusions reached by Finn \& Lawn (1968), yet it 
has not been definitely established that the electron-dense bodies are in fact derived from degenerating epithelial cells, nor that they are identical with the W-bodies observed by light microscopy. Again, dark granular inclusions were occasionally observed within embryonic cells of the inner cell mass (Pl. 16, Fig. 30), perhaps resembling the inclusion bodies that characterize Wilson's so-called 'primary invasive cells'. It was not possible to determine whether these inclusions constitute phagocytized cell débris, autophagic vacuoles or a cellular secretion product, and their relation to the W-bodies remains conjectural.

According to Finn \& McLaren (1967), the sequence of events after the shedding of the zona pellucida is: (i) Pontamine blue reaction; (ii) emergence of W-bodies; (iii) local oedema of the uterine stroma; (iv) histochemically demonstrable increase in endometrial alkaline phosphatase activity; and (v) histological decidualization. If, indeed, the Pontamine blue reaction precedes transfer of $\mathrm{W}$-bodies to the uterine epithelium, this would render the view that the W-bodies carry the decidua-inducing stimulus less likely. More recently, Wilson \& Smith (1968) reported transfer of RNA-like material, demonstrated autoradiographically, from the blastocyst to endometrial stromal cells. This observation is of great interest, though in view of the efficacy of simple mechanical stimuli in evoking decidualization it would seem surprising that elaborate exogenous information, such as might be conveyed by RNA, should be necessary to trigger off this process.

During the early phase of blastocyst attachment, bristle-coated membrane is often seen in trophoblast cells near the attachment site. Similar structures have been reported by several authors in other material (Roth \& Porter, 1963, 1964, mosquito oocyte; Bruni \& Porter, 1965, rat liver cell; Wyburn, Johnston \& Aitken, 1965, pre-ovulatory follicle of the fowl; Matsusaka, 1967, pigment epithelial cells of chicken retina). The 'vacuoles' observed by Potts \& Psychoyos (1967) in a delayed blastocyst of rat appear to belong to the same category of structures.

According to Roth \& Porter (1963, 1964) and Friend \& Farquhar (1967), the presence of bristle-coated membrane is indicative of a process of protein uptake. Thus, it is possible that following loss of the zona pellucida the blastocyst begins to take up macromolecular material from the uterine lumen or from the surface of epithelial cells. In the present study, structures were often observed in epithelial cells during the late attachment stage which resembled the coated vesicles described by Friend \& Farquhar (1967) in the vas deferens. These, in turn, may suggest protein uptake by epithelial cells.

\section{Initial contact between trophoblast and stromal cells}

Since the implanting blastocyst constitutes essentially a successful homograft, there is interest in the possible existence of a physical barrier preventing access of foetal antigens to maternal lymphoid cells. Such a barrier has been proposed by Kirby et al. (1964) and Bradbury et al. (1965) in the form of a layer of fibrinoid material, rich in sialic acid, coating the trophoblastic epithelium in the mouse. Alternatively, the trophoblastic surface might be devoid of transplantation antigens, as suggested by Simmons \& Russell (1962) and Simmons, 
Cruse \& McKay (1967): the latter authors failed to detect extra-cellular fibrinoid material in ectopic transplants of mouse trophoblast. The view of Kirby's group has recently received support from the work of Currie, van Doorninck \& Bagshawe (1968), who demonstrated the presence in mouse trophoblast cells of transplantation antigens that could be unmasked by treatment with neuraminidase.

In the initial stages of invasion (until the early morning of Day 7 p.c.), trophoblastic giant cells or cells forming the lateral lining of the blastocyst cavity eliminate the uterine epithelial cells, but leave the basement membrane temporarily intact. A similar transient persistence of the basement membrane following epithelial degeneration and disappearance was described by Larsen (1961) in the rabbit, and Alden (1948) was able to observe the penetration of trophoblastic giant cells between the epithelial cells and their basement membrane by light microscopy. However, by noon of Day 8 p.c. in the present study the basement membrane had vanished, and trophoblast cells appeared to be in intimate contact with stromal elements without any detectable intervening fibrinoid material. These observations do not preclude the possible existence of a molecular film of mucoprotein on the surface of trophoblast cells, nor the possibility that such a film may be adequate to provide an effective immunological barrier, though the close apposition (100 to $200 \AA$ ) of trophoblastic and stromal cell membranes makes this seem unlikely (cf. Mercer, 1964). Moreover, it is possible that a 'periplacental fibrinoid barrier' develops in the rat, too, at a later stage of gestation, since this structure was described in the eutopic mouse trophoblast only on the 16th day of pregnancy (Kirby et al., 1964; Bradbury et al., 1965). It is even conceivable that a transient immunological interaction between blastocyst and maternal tissues may in fact have a subsidiary rôle in decidual induction.

\section{Development of Reichert's membrane}

Wislocki \& Dempsy (1955) observed the fully developed Reichert's membrane on the 15th day of gestation. Observations on Reichert's membrane in 9-day-old rat embryos (Day 9 p.c.) were reported by Satow, Okamoto, Fukazawa, Ikeda, Shimada \& Imabashi (1966), and Enders \& Schlafke (1967) noted its presence on the 7th day of gestation when it formed a basementmembrane-like lining on the inner aspect of the trophoblast. The present authors were able to follow the structural development of this membrane from the earliest signs of its deposition at noon of Day 6 to its full development on Day 8 of pregnancy. Particularly noteworthy is the transformation of a thin streak of mildly electron-dense, amorphous material into a thick, laminated structure within a period of only about $24 \mathrm{hr}$. Of the several layers that can be recognized in the fully developed membrane, that closest to the trophoblast cell surface appears somewhat denser than the rest. Though the origin of the material that makes up Reichert's membrane could not be determined with certainty, it appeared that both the endodermal cells and the trophoblastic cells contribute to its formation. In the mouse, both an endodermal origin (Fawcett, 1950; Porter, 1966) and a trophoblastic origin (Amoroso, 1952) have been suggested for the substrate that forms this membrane. 
Phagocytic activity of the blastocyst and stromal cells

During elimination of the uterine epithelium, trophoblast cells actively engulf epithelial cells and digest them intracellularly. Supernumerary sperm inclusions were also seen in trophoblast cells, even after shedding of the zona. In addition to the trophoblast cells, other cell types at the implantation site also show phagocytic activity. Cells of the inner cell mass of an implanted blastocyst were seen engulfing a sperm tail, possibly derived from the fertilizing spermatozoon. The retention of components of spermatozoa in a blastocyst of such an advanced stage has not previously been reported. Furthermore, erythrophagocytosis was observed in stromal cells, a capacity not previously attributed to this cell type. Diapedesis of the formed elements of blood is common during the incipient decidual reaction, and in conjunction with the local oedema gives the endometrium an appearance reminiscent of an acute inflammatory process.

\section{Differentiation of the decidual cell}

During nidus formation, the stromal cells in adjacent sub-epithelial regions show characteristic morphological changes. Apart from the nuclear changes already alluded to, bundles of fine fibrillar material are accumulated intracellularly and eventually occupy a large portion of the cytoplasm. The presence of such fibrillar material has been reported in trauma-induced deciduomata (Jollie \& Bencosme, 1965) and in the nidus during natural implantation in rats (Enders \& Schlafke, 1967), but the fibrils shown were sparse and did not form massive accumulations as seen in the present material. The bundles are particularly conspicuous in the cells that lie close to the invading trophoblast on Day 8 p.c. The fibrils can first be recognized in early decidual cells and increase in amount as decidualization proceeds, when they become packed in highly regular, parallel bundles along the cell surface. Morphological analogues of these fibrils have been described in fibroblasts (cf. Ross, 1968), mononuclear phagocytes (de Petris, Karlsbad \& Pernis, 1962), endothelial cells (Cecio, 1967) and in several types of neoplastic cells, e.g. hepatomata (Usui, 1967). The chemical nature of the decidual fibrillar material is unknown, and its characterization may shed some light on the derivation of the decidual cell.

\section{ACKNOWLEDGMENTS}

We are grateful to Professor M. C. Shelesnyak for the interest taken in this work. We are indebted to $\mathrm{Mr} \mathrm{H}$. Shelesnyak and $\mathrm{Mr} \mathrm{S}$. Himmelhoch for photographic reproductions, to Mr J. Shalom for devoted animal care, and to Professor D. Danon for generous permission to use some of his facilities. One of us (G.T.) was a Population Council Fellow (1965-67). The work was supported by grants from the Ford Foundation and the Population Council, N.Y.

\section{REFERENCES}

ALDEN, R. H. (1948) Implantation of the rat egg. III. Origin and development of primary trophoblast giant cells. Am. F. Anat. 83, 143.

Amoroso, E. C. (1952) Placentation. In: Marshall's Physiology of Reproduction, Vol. II, p. 127. Ed. A. S. Parkes. Longmans, Green, London. 
Blandau, R. J. (1949) Embryo-endometrial interrelationship in the rat and guinea pig. Anat. Rec. 104, 331.

Blandau, R. J. (1961) Biology of eggs and implantation. In: Sex and Internal Secretions, Vol. II, 3rd edn, p. 797. Ed. W. C. Young. Williams and Wilkins, Baltimore.

Boyd, J. D. \& Hamilton, W. J. (1952) Cleavage, early development and implantation of the egg. In: Marshall's Physiology of Reproduction, Vol. II, p. 1. Ed. A. S. Parkes. Longmans, Green, London.

Bradbury, S., Billington, W. D. \& Kirby, D. R. S. (1965) A histochemical and electron microscopical study of the fibrinoid of the mouse placenta. $f l$ R. microsc. Soc. 84, 199.

BRUNT, C. \& PORTER, K. R. (1965) The fine structure of the parenchymal cell of the normal rat liver. Am. F. Path. 46, 691.

CECIO, A. (1967) Ultrastructure features of cytofilaments within mammalian endothelial cells. $Z$. Zellforsch. mikrosk. Anat. 83, 40.

Currie, G. A., van Doorninck, W. \& Bagshawe, K. D. (1968) Effect of neuraminidase on the immunogenicity of early mouse trophoblast. Nature, Lond. 219, 191.

De Feo, V. J. (1967) Decidualization. In: Cellular Biology of the Uterus, p. 191. Ed. R. M. Wynn. Appleton-Century-Crofts, New York.

de Petris, S., Karlsbad, G. \& Pernis, B. (1962) Filamentous structures in the cytoplasm of normal mononuclear phagocytes. $\mathcal{7}$. Ultrastruct. Res. 7, 39.

ENDERs, A. C. (1964) Electron microscopy of an early implantation stage, with a postulated mechanism of implantation. Devl Biol. 10, 395.

Enders, A. C. \& Schlafke, S. J. (1965) The fine structure of the blastocyst: some comparative studies. In: Preimplantation Stages of Pregnancy, p. 29. Eds. G. E. W. Wolstenholme and M. O'Connor. Churchill, London.

Enders, A. C. \& Schlafke, S. (1967) A morphological analysis of the early implantation stages in the rat. Am. F. Anat. 120, 185.

FAwCETt, D. W. (1950) The development of mouse ova under the capsule of the kidney. Anat. Rec. $108,71$.

Fins, C. A. \& Lawn, A. M. (1968) Transfer of cellular material between the uterine epithelium and trophoblast during the early stages of implantation. F. Reprod. Fert. 15, 333.

Finn, C. A. \& McLaren, A. (1967) A study of the early stages of implantation in mice. J. Reprod. Fert. $13,259$.

Friend, D. S. \& FARQUHAR, M. G. (1967) Functions of coated vesicles during protein absorption in the rat vas deferens. F. Cell Biol. 35, 357.

HARkNess, R. D. (1964) The physiology of the connective tissues of the reproductive tract. Int. Rev. connect. Tissue Res. 2, 155.

Jollie, W. P. \& Bencosme, S. A. (1965) Electron microscopic observations on primary decidua formation in the rat. Am. J. Anat. 116, 217.

KARNovsKy, M.J. (1961) Simple methods for "staining with lead" at high $\mathrm{pH}$ in electron microscopy. 7. biophys. biochem. Cytol. 11, 729.

Kirby, D. R. S., Billington, W. D., Bradbury, S. \& Goldstein, D. J. (1964) Antigen barrier of the mouse placenta. Nature, Lond. 204, 548.

KraICER, P. F. (1967) Studies on the mechanism of nidation. XXIV. Isolation and study of intrauterine ova from the rat: technique and observations. Int. F. Fert. 12, 320.

Larsen, J. F. (1961) Electron microscopy of the implantation site in the rabbit. Am. 7. Anat. 109, 319.

Lobel, B. L., Levy, E. \& Shelesnyak, M. C. (1967) Studies on the mechanism of nidation. XXXIV. Dynamics of cellular interactions during progestation and implantation in the rat. Acta endocr., Copenh. 56, Suppl. 123, 7.

MatsusakA, T. (1967) The intracytoplasmic channel in pigment epithelial cells of the chick retina. $Z$. Zellforsch. mikrosk. Anat. 81, 100.

Meek, G. A. (1963) Discussion following paper by E. H. Mercer: A scheme for section staining in electron microscopy. $f l$ R. microsc. Soc. 81, 179.

Mercer, E. H. (1964) The external surface of the cell and intercellular adhesion. In: Recent Progress in Surface Science, Vol. 1, p. 360. Eds. J. F. Danielli, K. G. A. Pankhurst and A. C. Riddiford. Academic Press, New York and London.

Millonig, G. (1961) Advantages of phosphate buffer for $\mathrm{OsO}_{4}$ solutions in fixation. 7. appl. Phys. 32, 1736.

NiLsson, O. (1958) Ultrastructure of mouse uterine surface epithelium under different estrogenic influences. 2. Early effect of estrogen administered to spayed animals. F. Ultrastruct. Res. 2, 73.

NiLsson, O. (1966a) Estrogen-induced increase of adhesiveness in uterine epithelium of mouse and rat. Expl Cell Res. 43, 239.

NiLsson, O. (1966b) Structural differentiation of luminal membrane in rat uterus during normal and experimental implantations. Z. Anat. EntwGesch. 125, 152. 
NiLsson, O. (1967) Attachment of rat and mouse blastocysts on to uterine epithelium. Int. F. Fert. 12, 5.

Porter, D. G. (1966) Observations on the yolk sac and Reichert's membrane of ectopic mouse embryo. Anat. Rec. 154, 847.

Potrs, D. M. (1968) The ultrastructure of implantation in the mouse. F. Anat. 103, 77.

Potrs, M. (1966) The attachment phase of ovoimplantation. Am. F. Obstet. Gynec. 96, 1122.

Potrs, M. \& Psychoyos, A. (1967) Evolution de l'ultrastructure des relations ovo-endométriales sous l'influence de l'oestrogène, chez la ratte en retard expérimental de nidation. C.r. hebd. Séanc. Acad. Sci., Paris, série D, 264, 370.

Reichert, G. B. (1862) Beiträge zur Entwicklungsgeschichte des Meerschweinchens. Abhandl. Akad. Wissensch., Berlin. Cited from Boyd \& Hamilton (1952).

ReInIUs, S. (1967) Ultrastructure of blastocyst attachment in the mouse. Z. Zellforsch. mikrosk. Anat. 77, 257.

Ross, R. (1968) The fibroblast and wound repair. Biol. Rev. 43, 51.

Roth, T. F. \& Porter, K. R. (1963) Membrane differentiation for protein uptake. Fedn Proc. Fedn Am. Socs exp. Biol. 22, 178.

Roth, T. F. \& Porter, K. R. (1964) Yolk protein uptake in the oocyte of the mosquito Aedes aegypti L. 7. Cell Biol. 20, 313.

Sabatini, D. D., Bensch, K. \& Barrnett, R. J. (1963) Cytochemistry and electron microscopy. The preservation of cellular ultrastructure and enzymatic activity by aldehyde fixation. $\mathcal{F}$. Cell Biol. 17, 19.

Satow, Y., Okamoto, N., Fukazawa, K., Ikeda, T., Shimada, K. \& Imabashi, T. (1966) Electron microscopic observation on embryos of the 8th day of gestation in the rat. Hiroshima F. med. Sci. $15,407$.

Schlafke, S. \& Enders, A. C. (1967) Cytological changes during cleavage and blastocyst formation in the rat. F. Anat. 102, 13.

Shelesnyak, M. C. (1957) Some experimental studies on the mechanism of ova-implantation in the rat. Recent Prog. Horm. Res. 13, 269.

Shelesnyak, M. C., Marcus, G. J. \& Lindner, H. R. (1969) Determinants of the decidual reaction. In: Proc. IInd Int. Seminar on Human Reproduction and Sexual Endocrinology, Brussels.

Simmons, R. L., CRuse, V. \& McKay, D. G. (1967) The immunologic problem of pregnancy. II. Ultrastructure of isogeneic and allogeneic trophoblastic transplants. Am. F. Obstet. Gynec. 97, 218.

Srmmons, R. L. \& Russell, P. S. (1962) The antigenicity of mouse trophoblast. Ann. N.Y. Acad. Sci. 99, 717.

TACHI, S. \& KRAICER, P. F. (1967) Studies on the mechanism of nidation. XXVII. Sperm-derived inclusions in the rat blastocyst. F. Reprod. Fert. 14, 401.

TACHI, S., TACHI, G. \& Lindner, H. R. (1969) Gilia-bearing stromal cells in the rat uterus. F. Anat. 104, 295.

UsuI, T. (1967) Electron microscopic study on the ascites hepatoma, comparative observations. Gann, $58,229$.

WARREn, R. H. \& Enders, A. C. (1964) An electron microscopic study of the rat endometrium during delayed implantation. Anat. Rec. 148, 177.

WrLson, I. B. (1963) A new factor associated with the implantation of the mouse egg. F. Reprod. Fert. $5,281$.

Wilson, I. B. \& Sмгтн, M. S. R. (1968) Isotopic labelling of the mouse blastocyst. F. Reprod. Fert. 16, 305.

Wrstocki, G. B. \& Dempsy, E. W. (1955) Electron microscopy of the placenta of the rat. Anat. Rec. 123, 33.

Wyburn, G. M., Johnston, H. S. \& Artken, R. N. C. (1965) Specialized plasma membranes in the preovulatory follicle of the fowl. Z. Zellforsch. mikrosk. Anat. 68, 70.

\section{EXPLANATION OF PLATES 1 TO 16}

\section{PLATE 1}

Fic. 1. Blastocyst with zona pellucida, in utero. Day 5 p.c., 11.00 hours. The blastocyst is in contact with the microvilli of epithelial cells. The tips of the epithelial cells are vacuolated. Dark granular bodies (arrow) are seen in the zona. The upper cell is a trophoblast cell. $\mathrm{Er}$, endoplasmic reticulum; $\mathrm{M}$, mitochondrion; $\mathrm{Mv}$, microvilli; $\mathrm{N}$, nucleus; $\mathrm{Np}$, nuclear pore; PI, plaques; Troph, trophoblast cell; V, vacuoles; U. Ep, uterine epithelial cell. 


\section{PLATE 1}

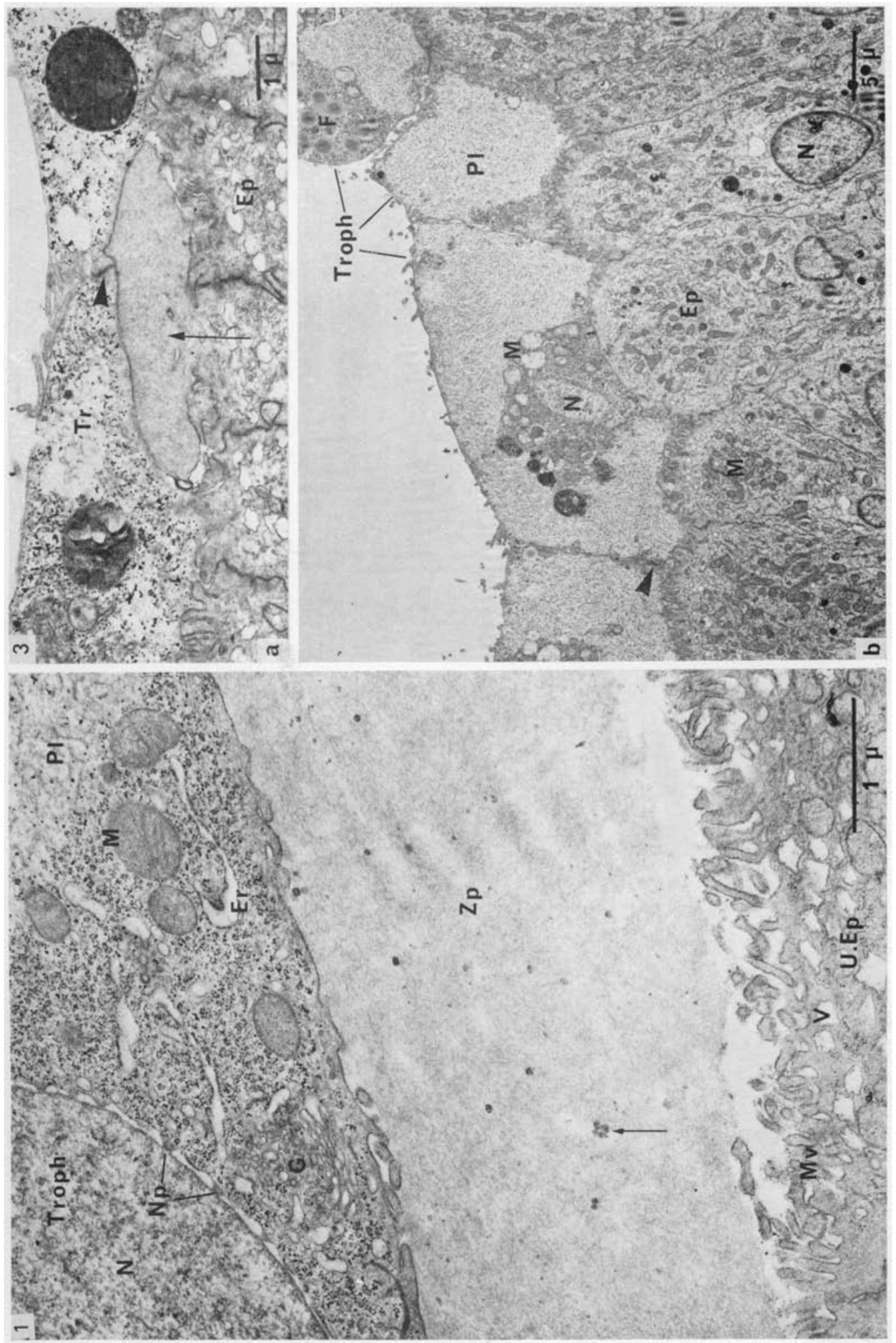


PIATF, 2

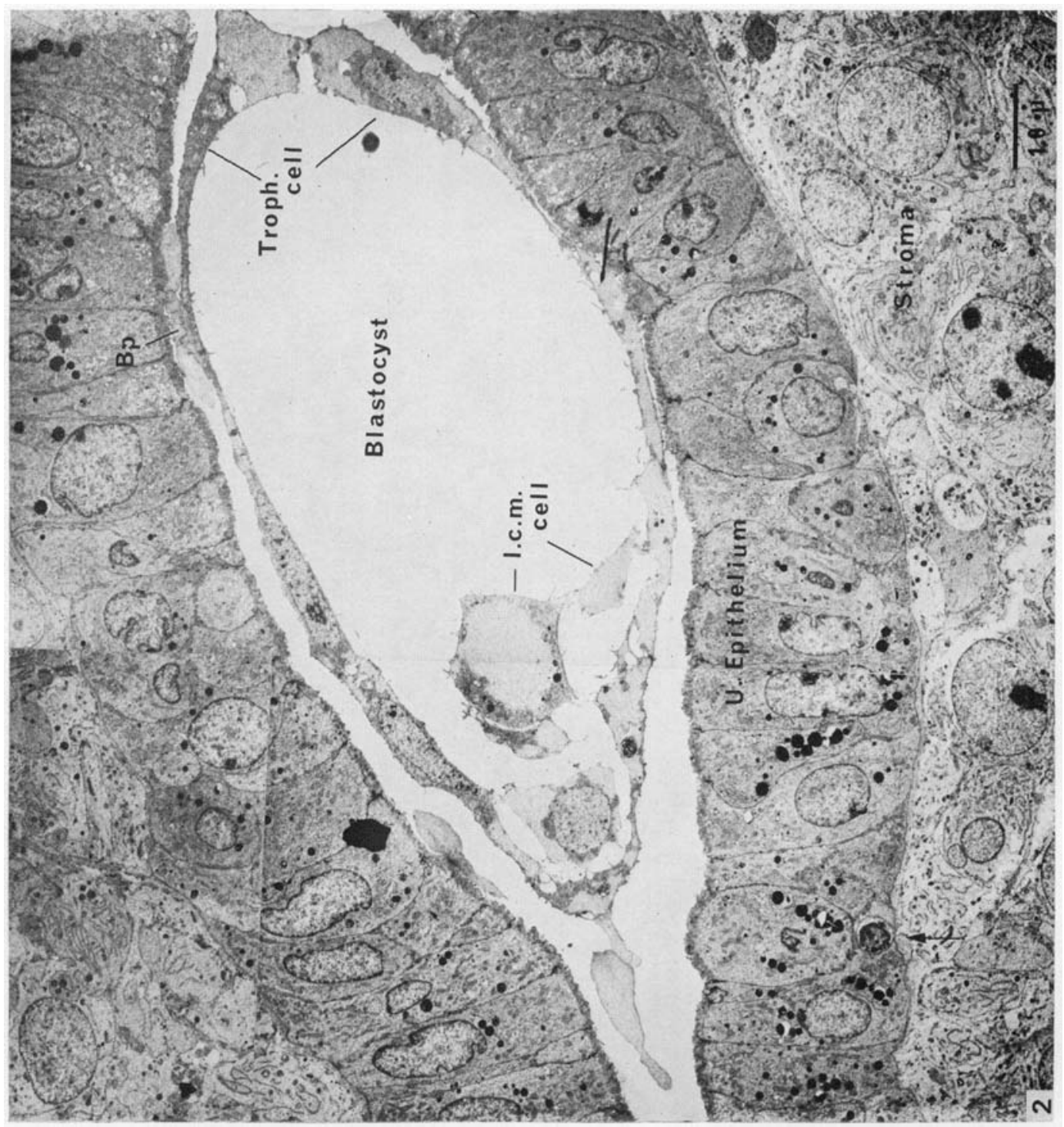


PLATE 3
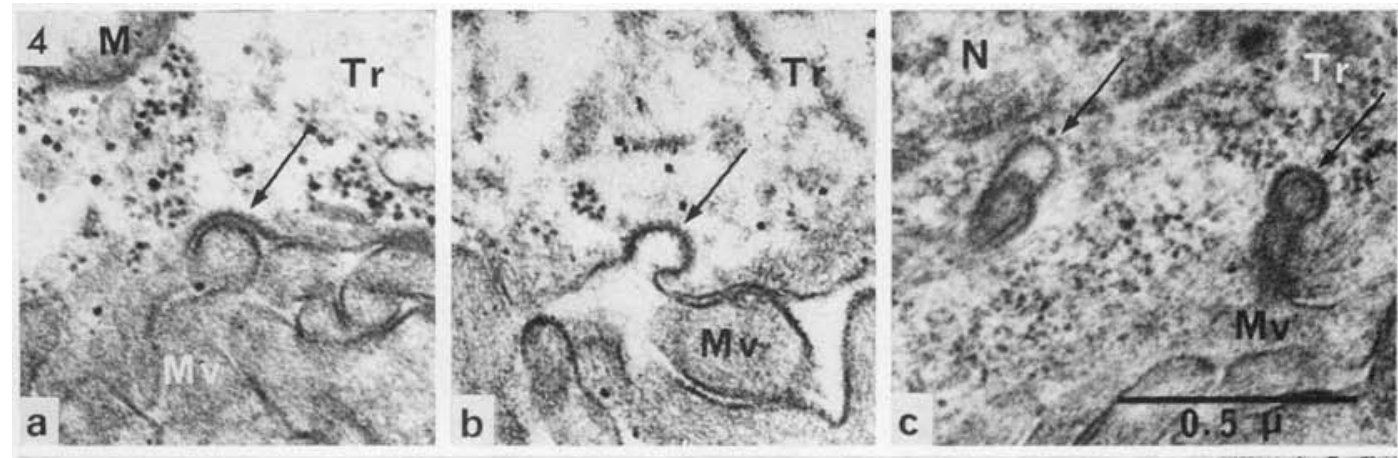

5

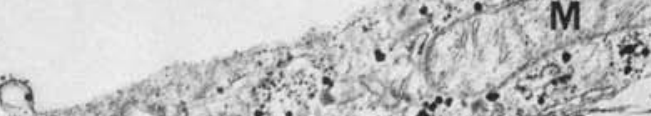

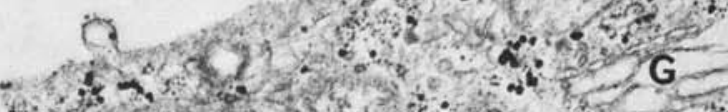

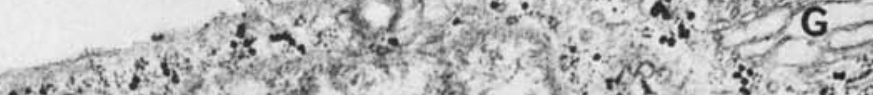

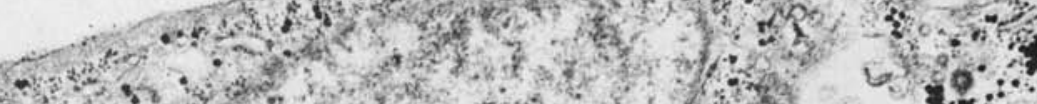

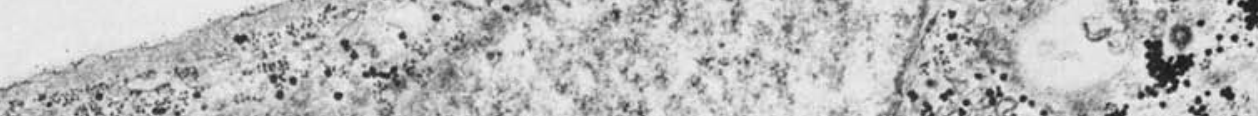

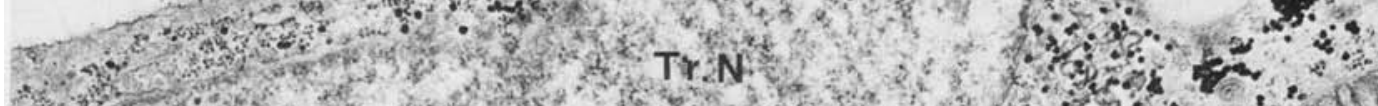

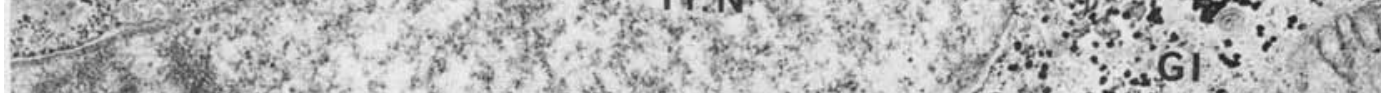

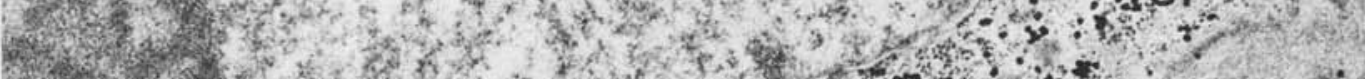

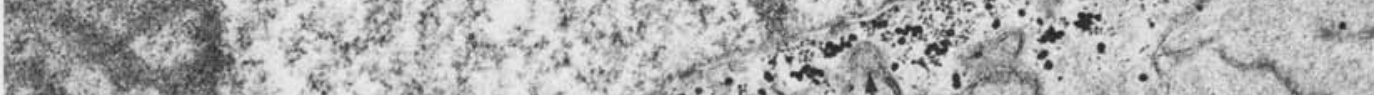

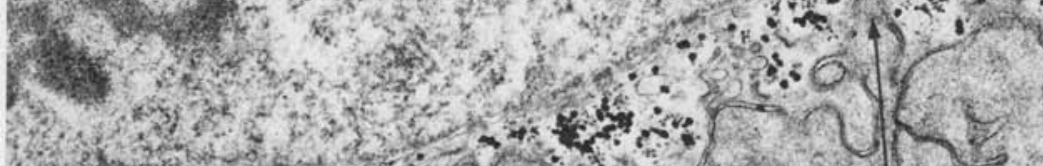

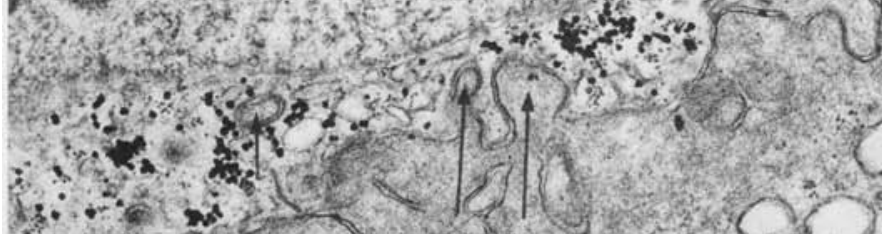
S.,, 0.20 2. 3.200

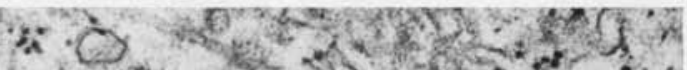

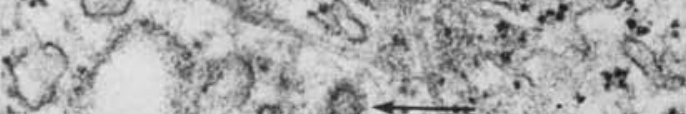

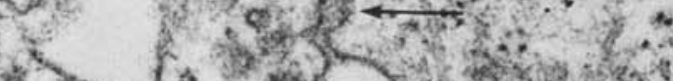

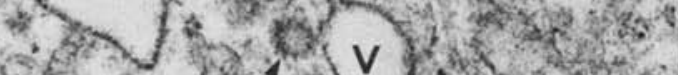

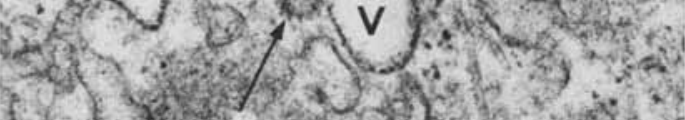

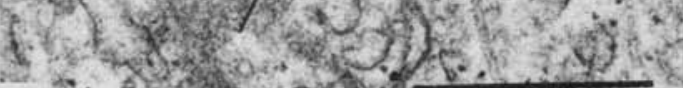

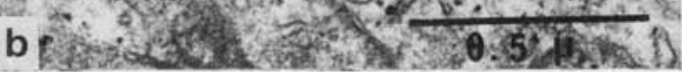


PLATE 4
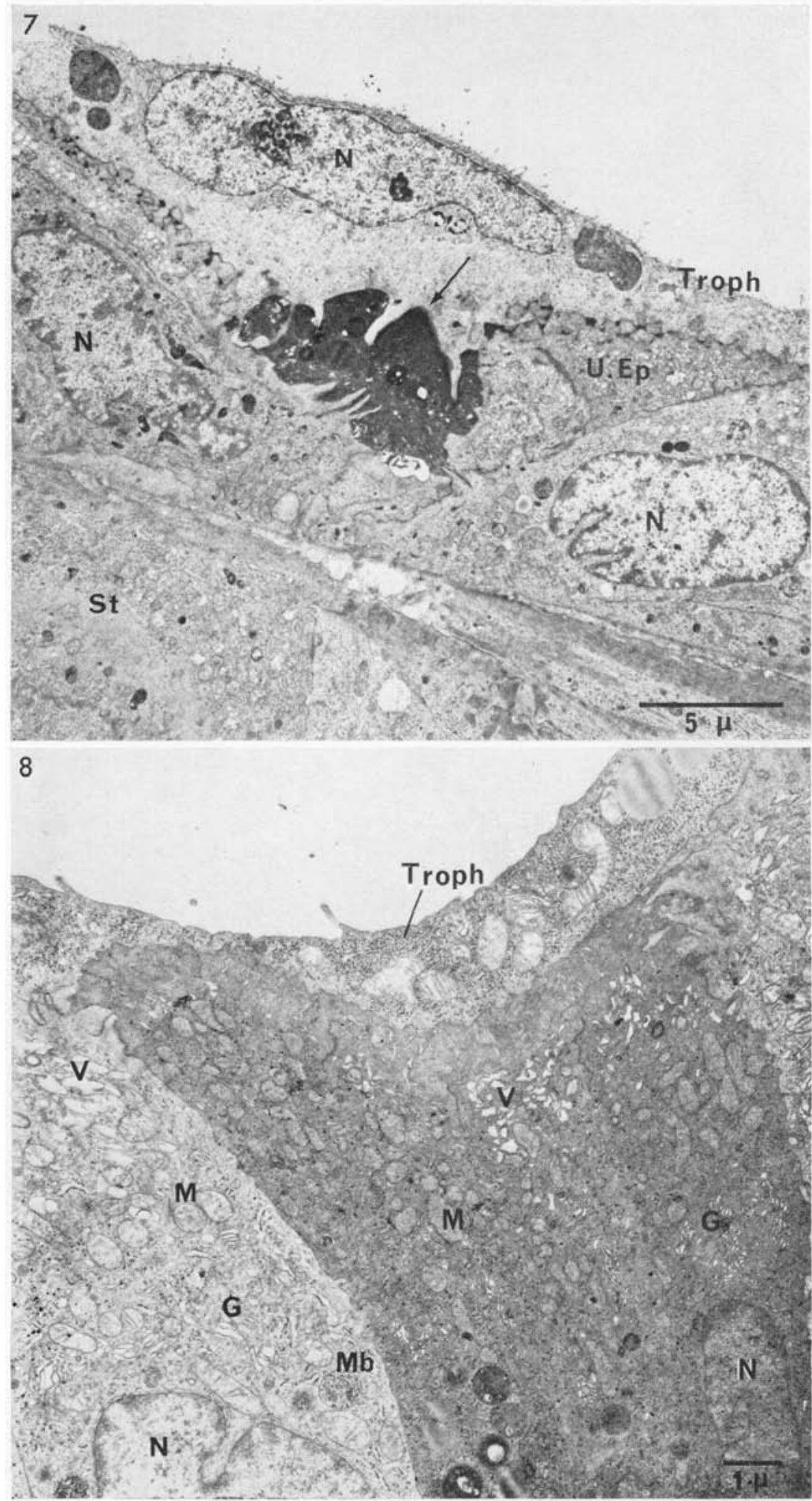
PLATE 5

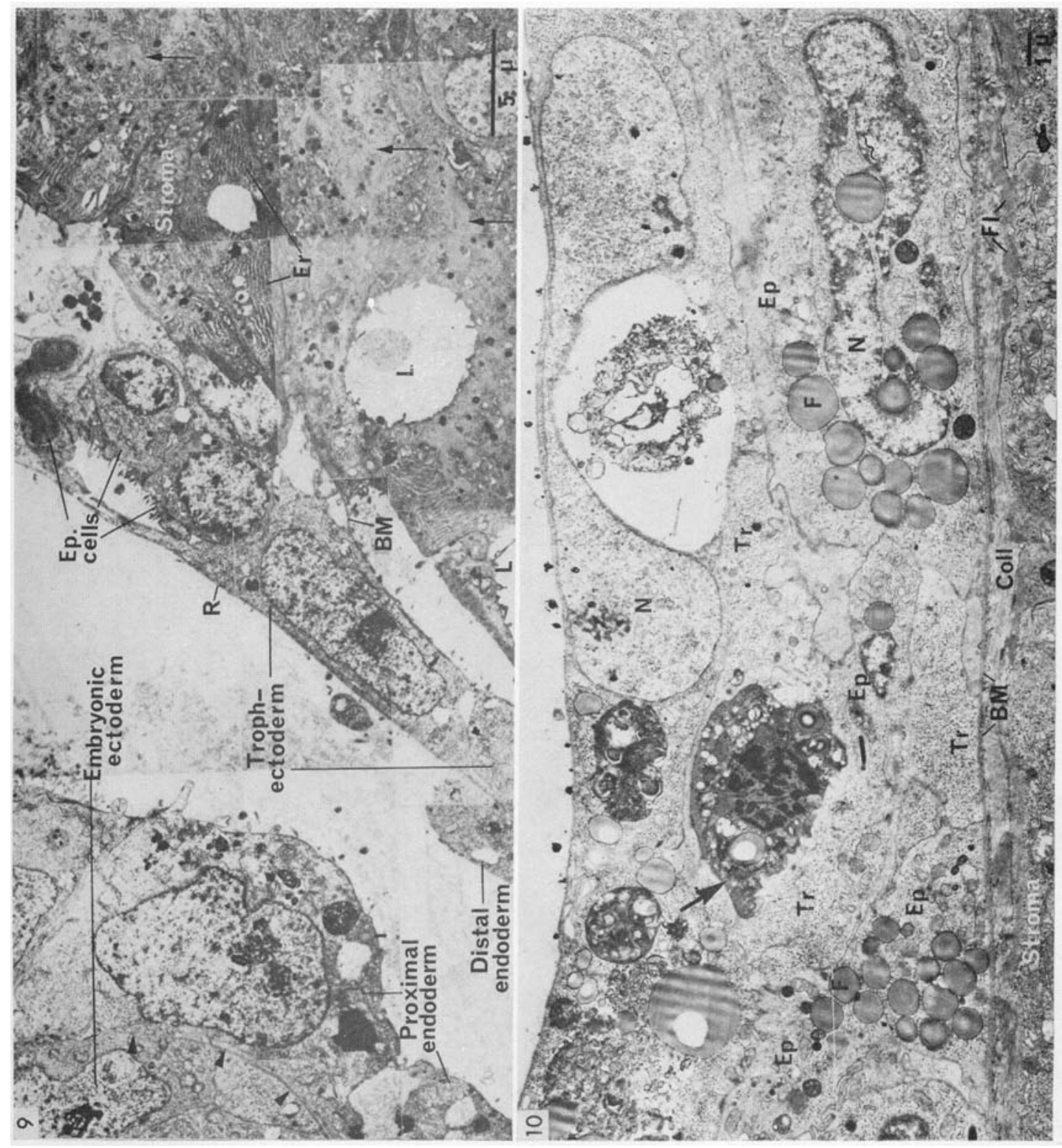




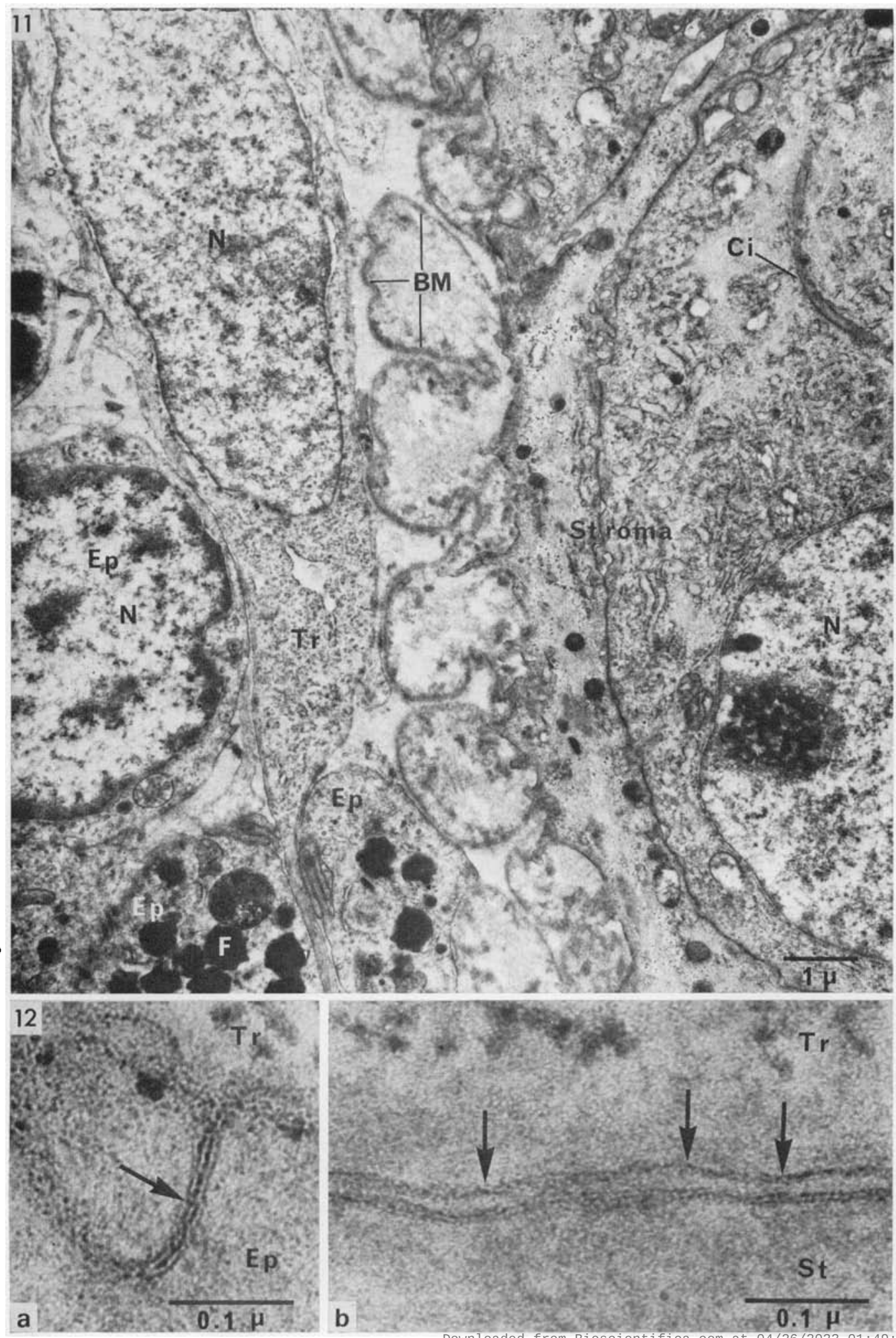



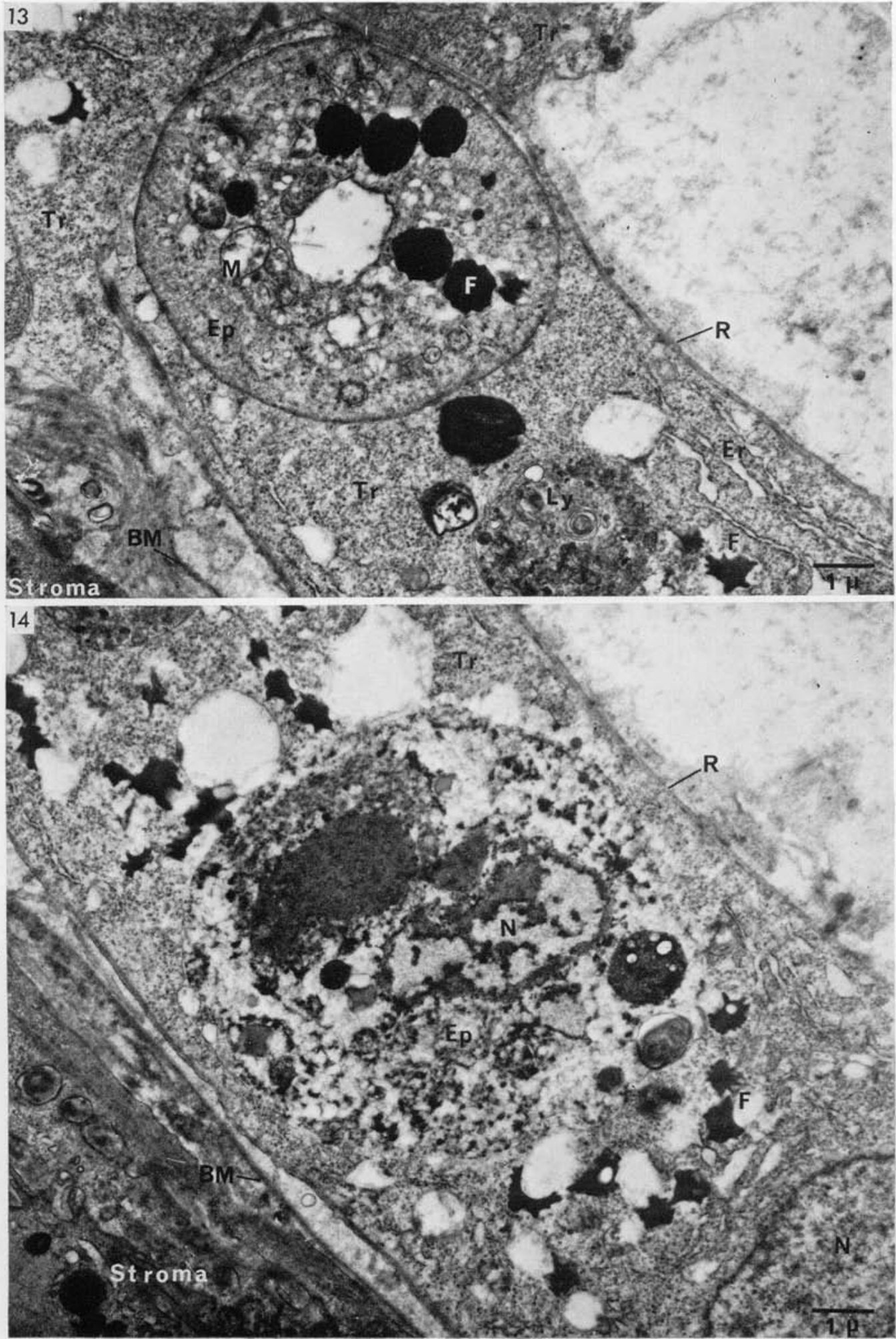
PL.ATE 8

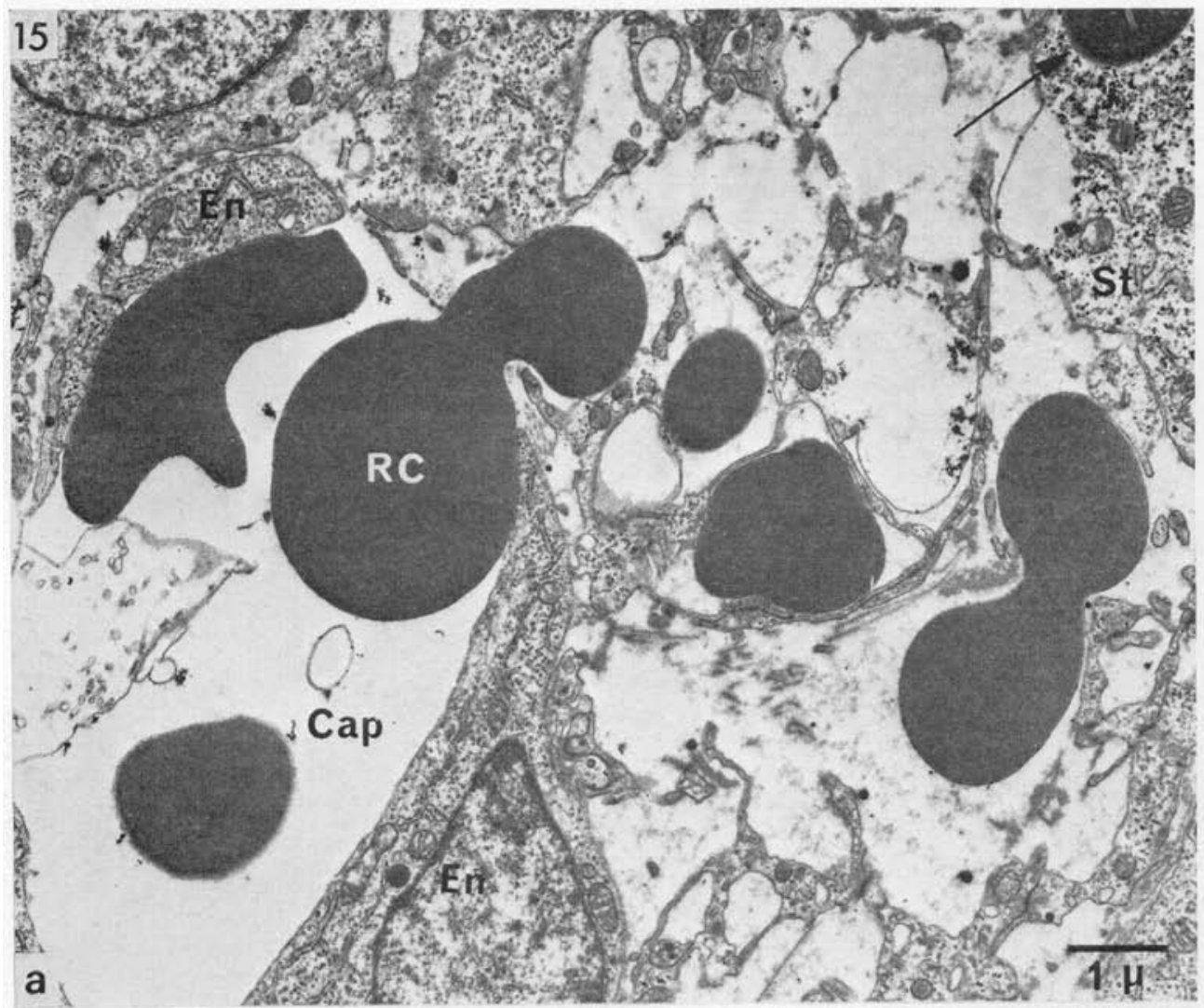

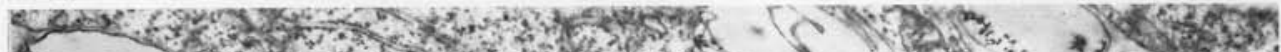
(5)

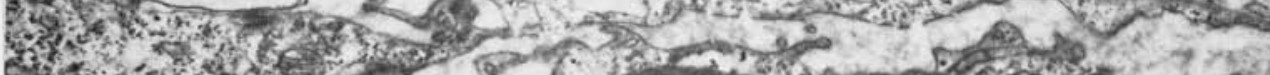

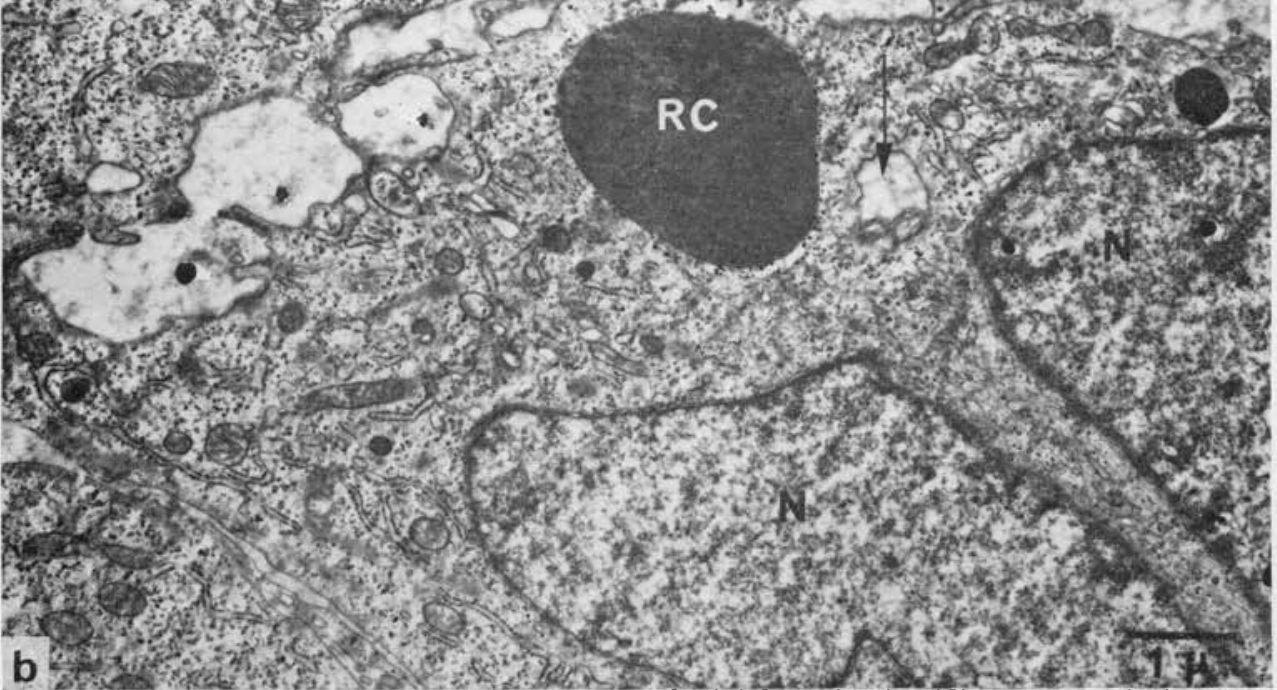


PIATE 9

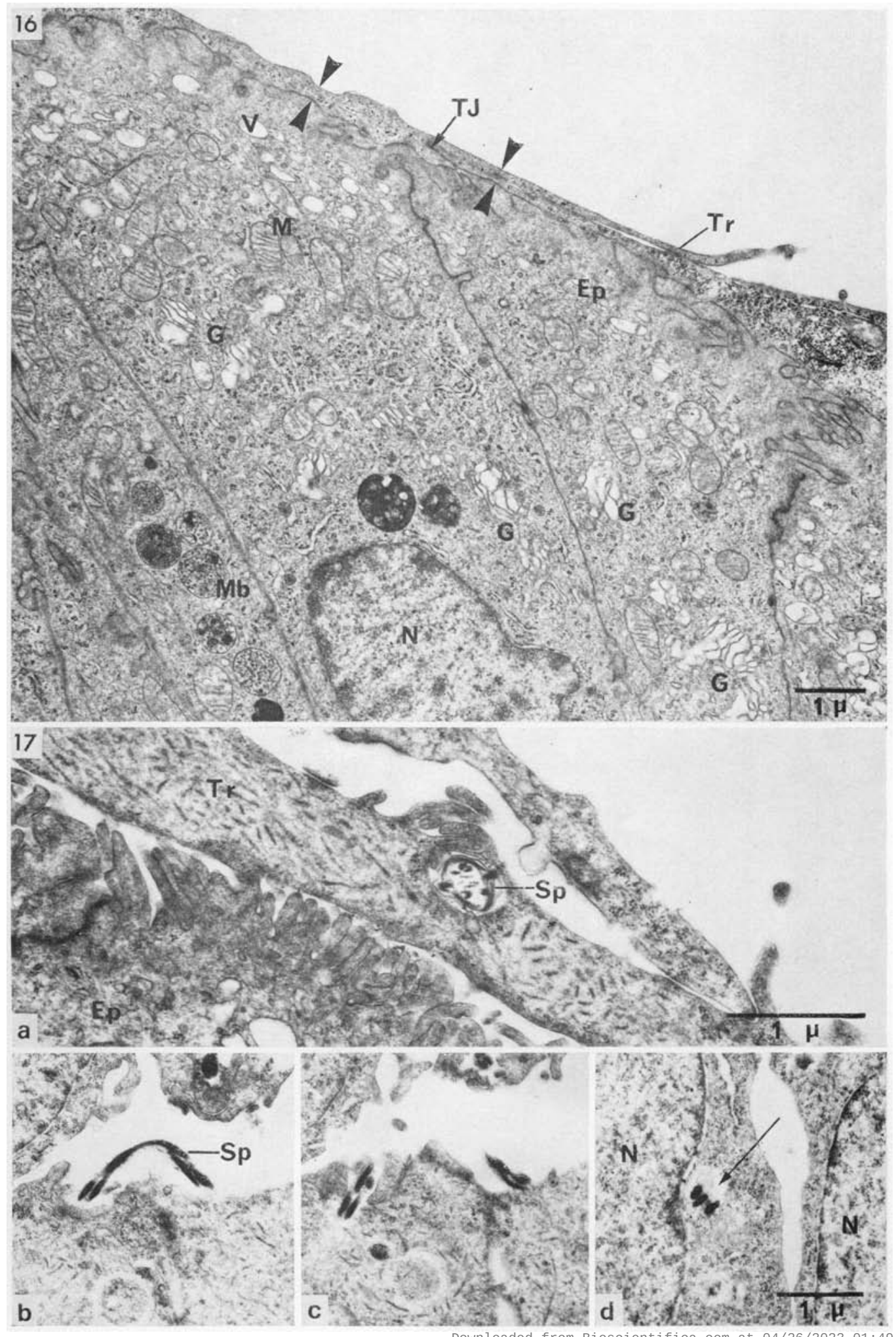


PLATE 10

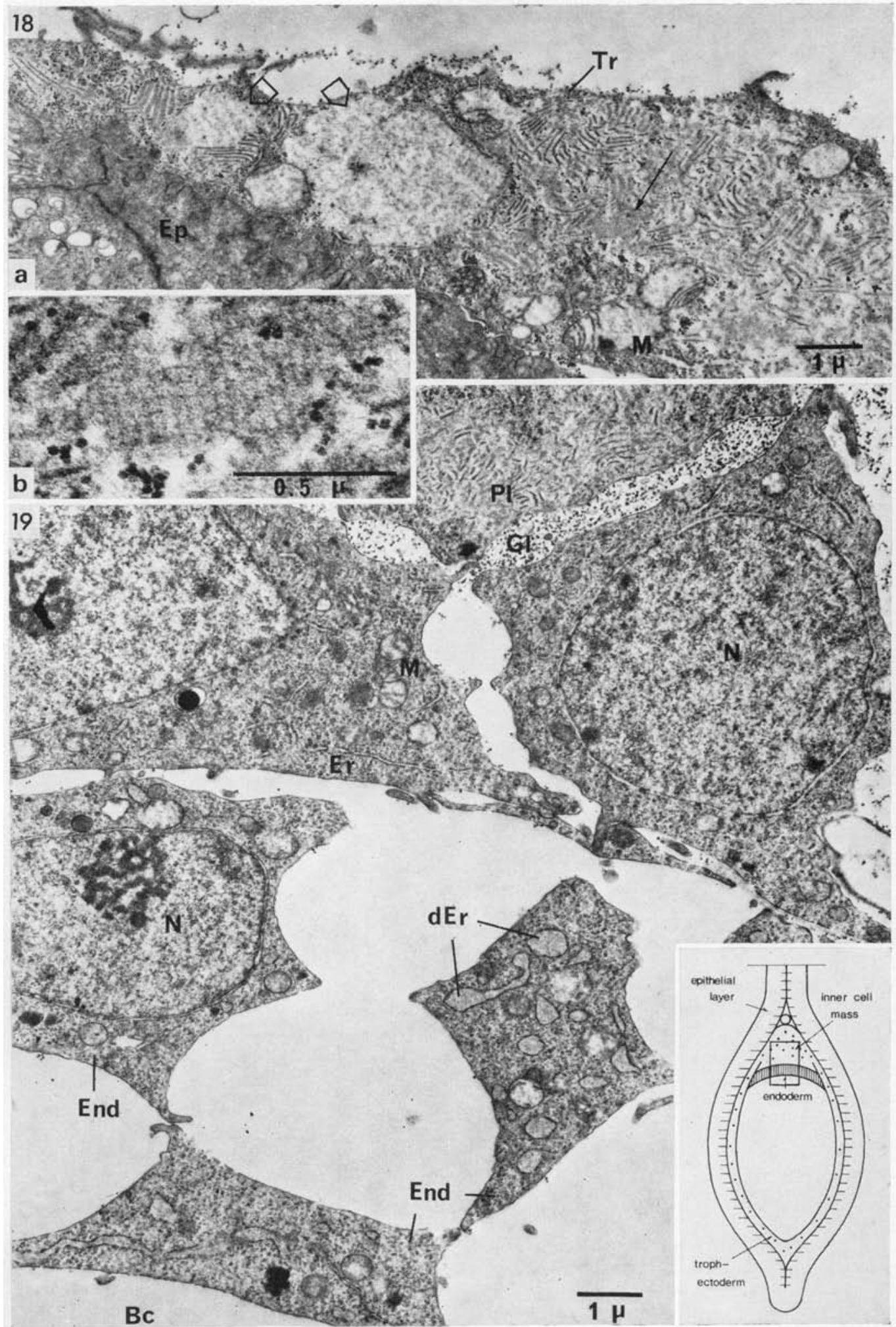


PI.ATE 11

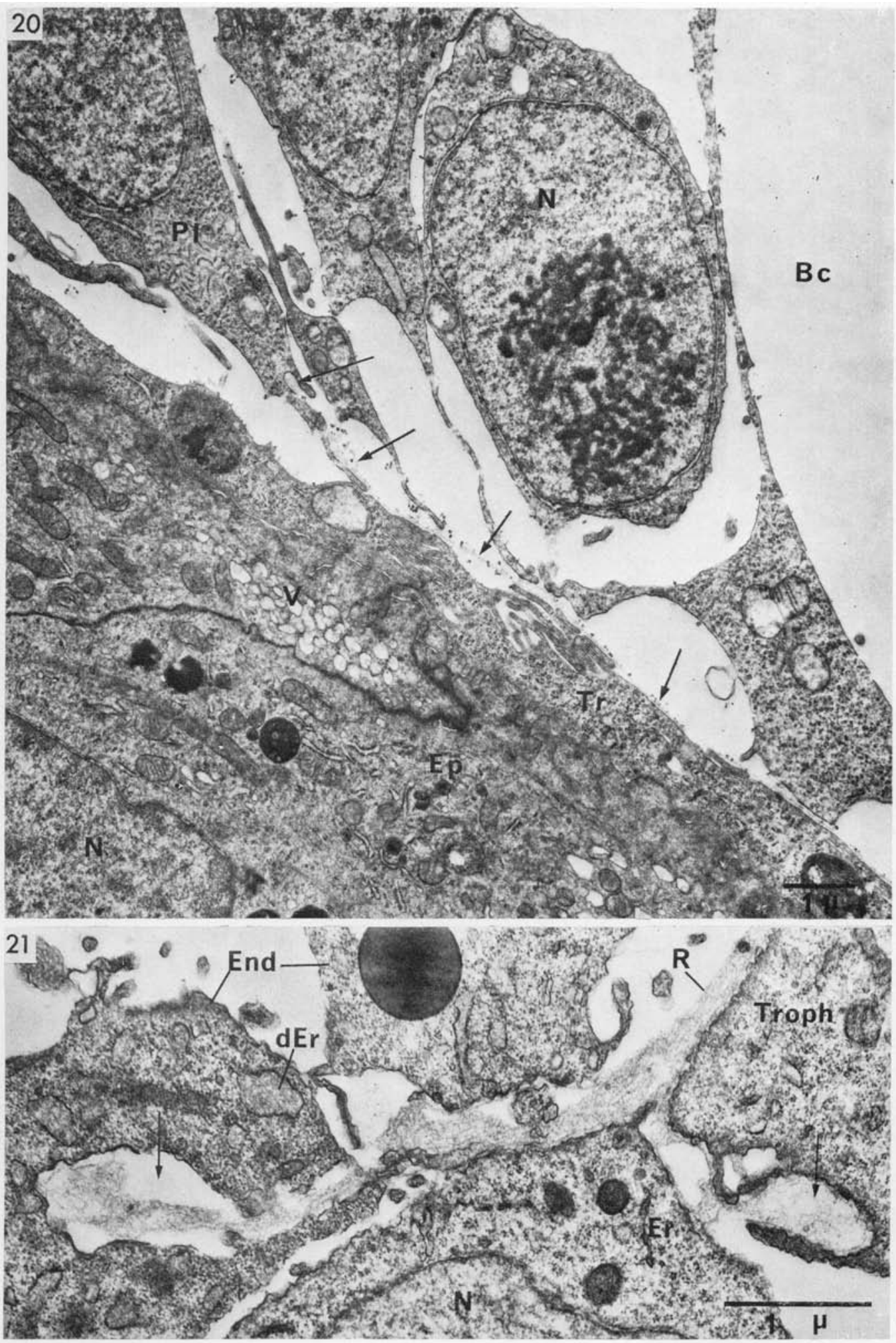



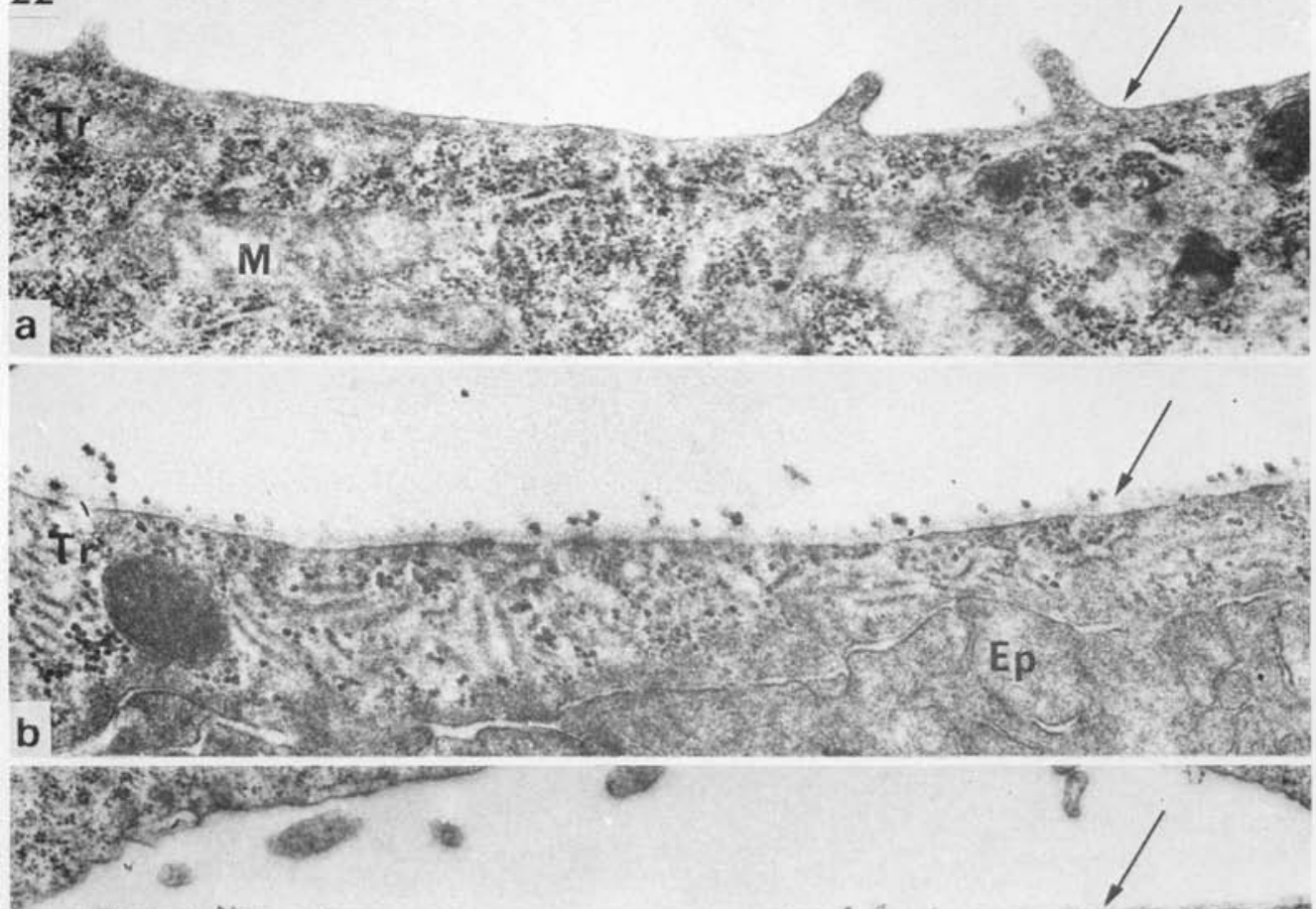

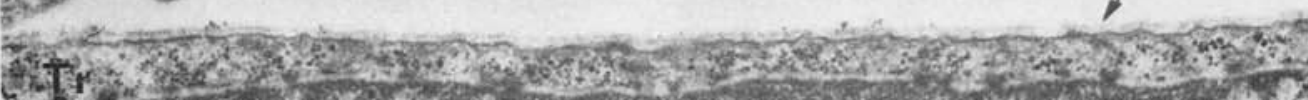

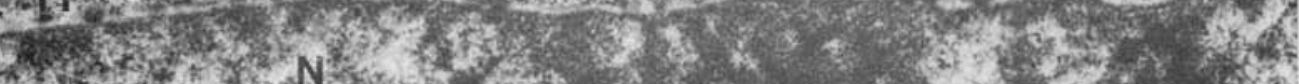
M.

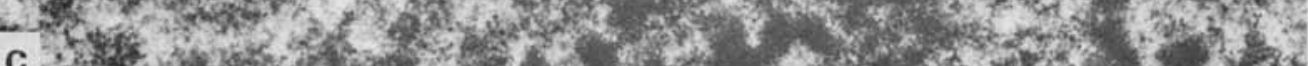

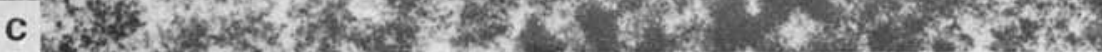

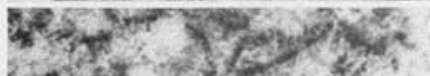

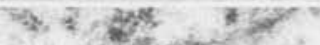

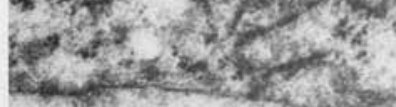

W.

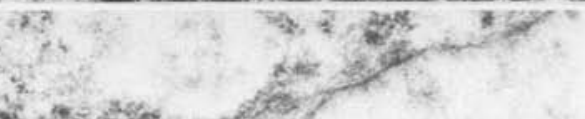

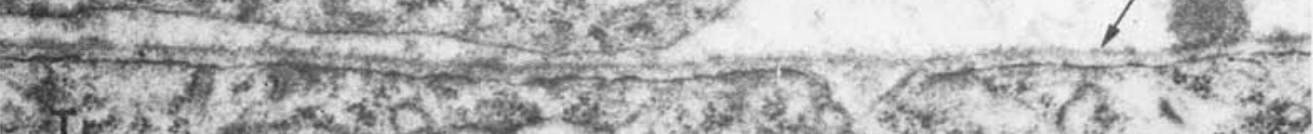

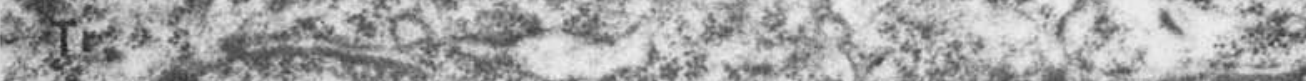

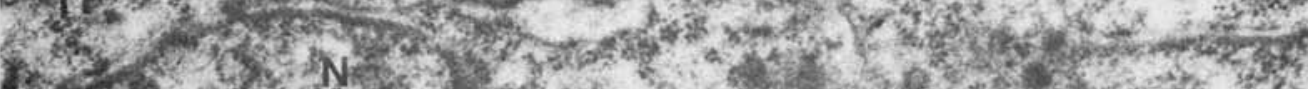

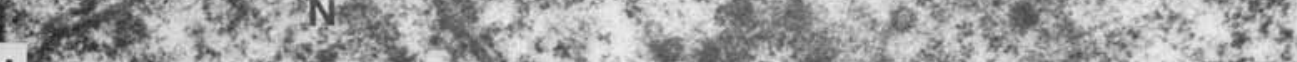

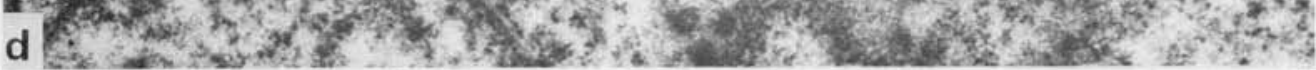

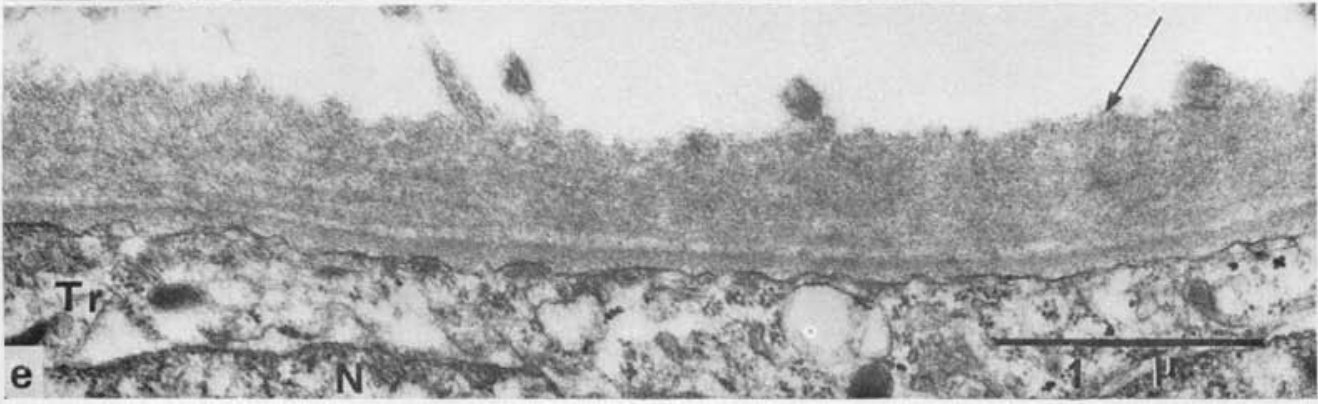



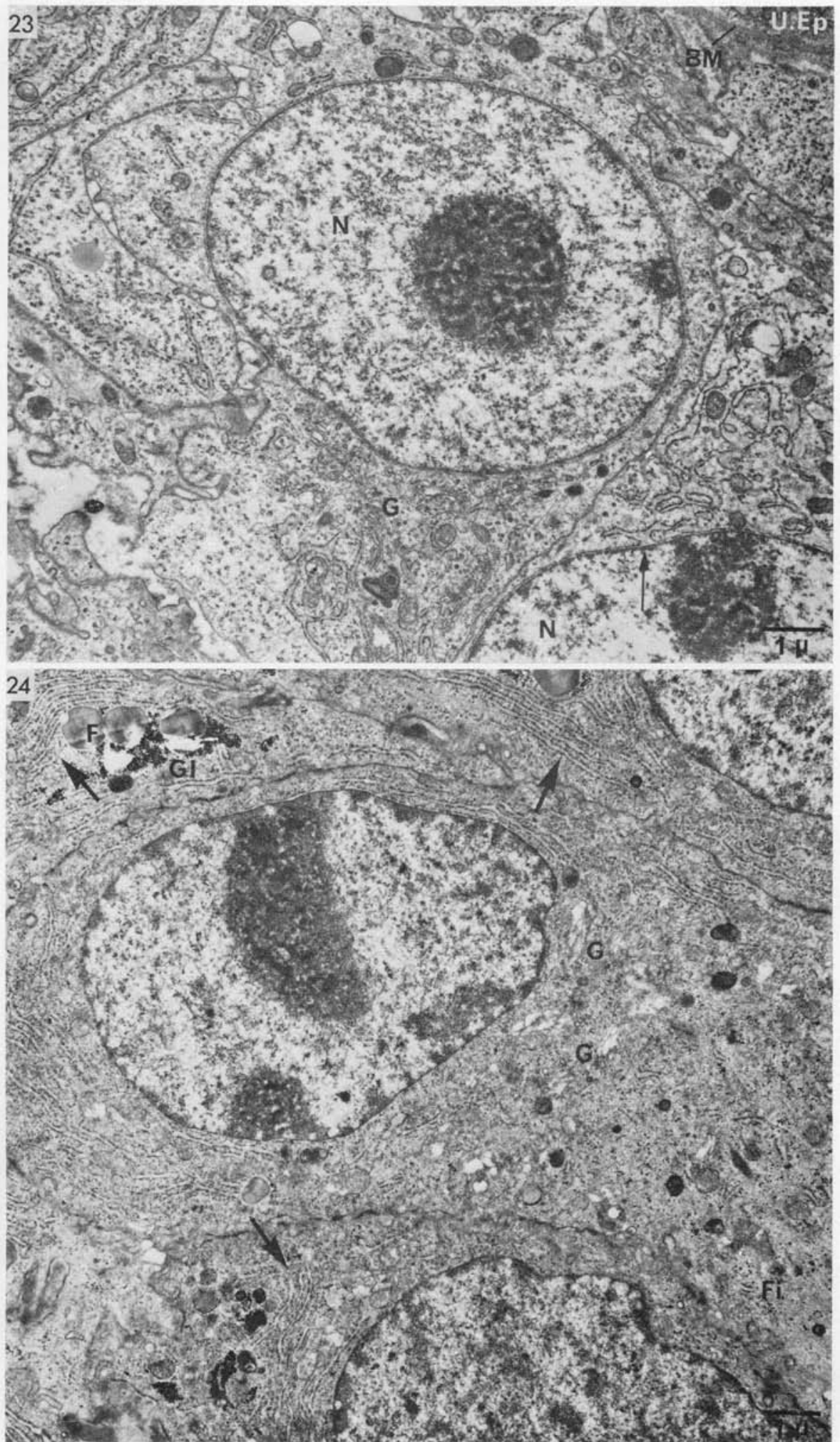
PLATE 14

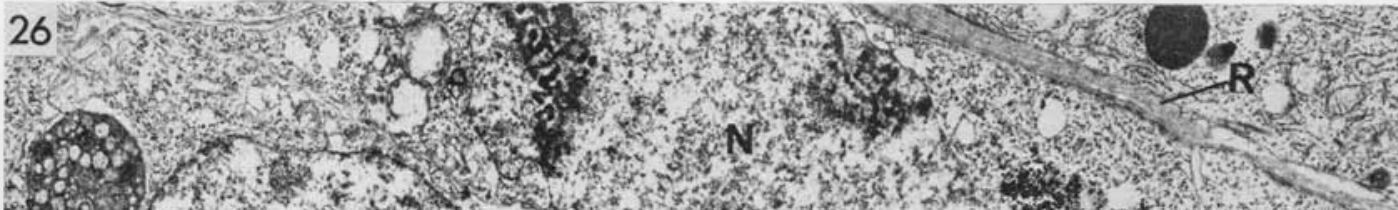

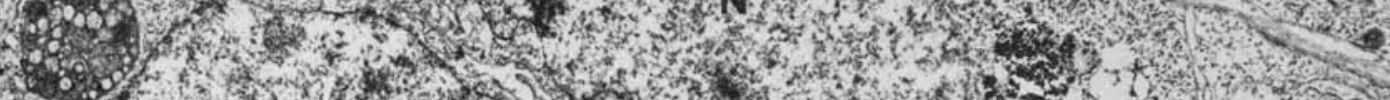

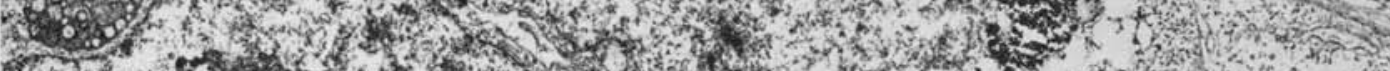

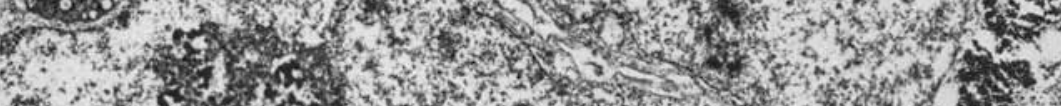
th

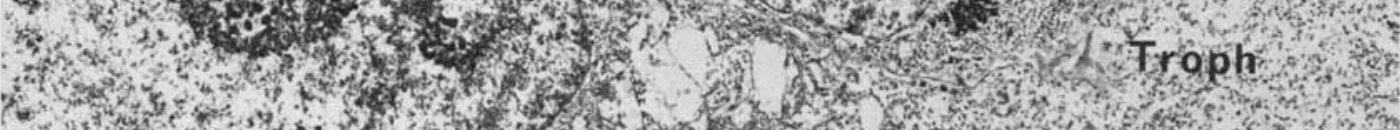

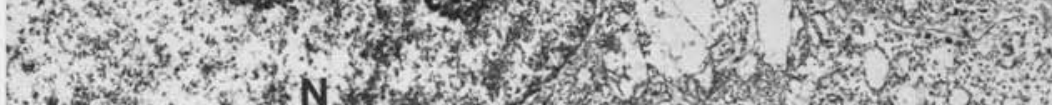

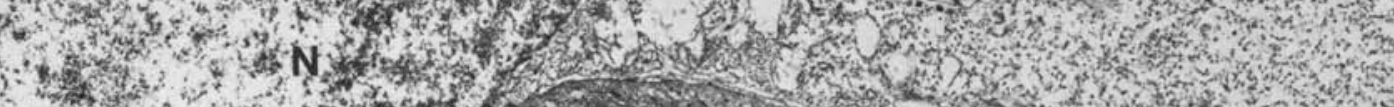

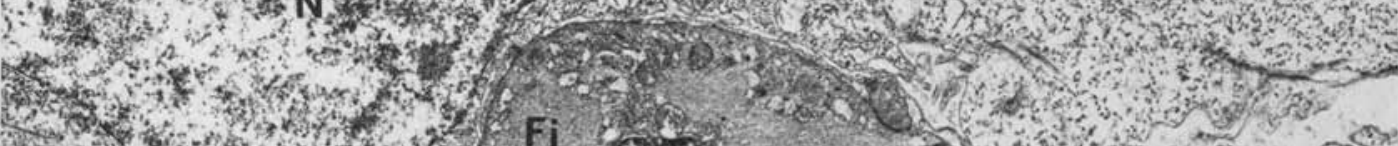

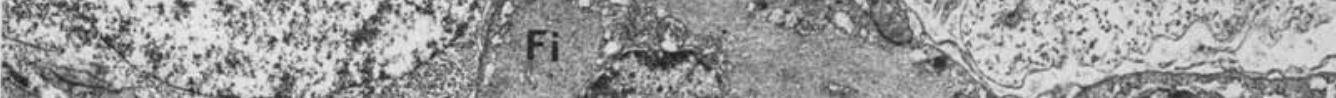

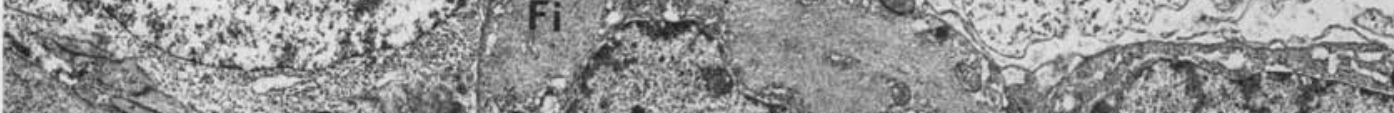

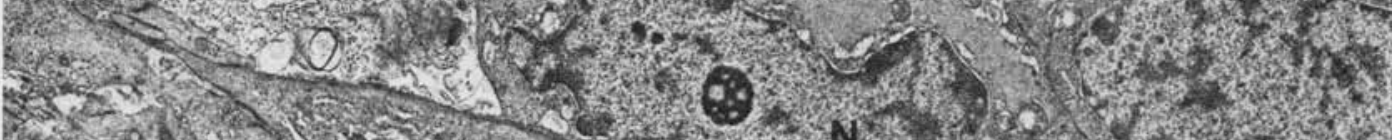

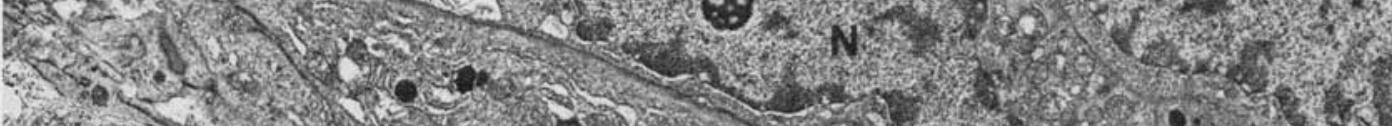

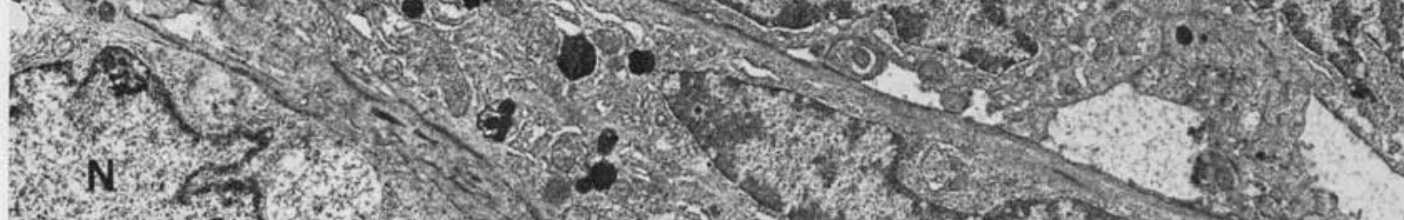
1.
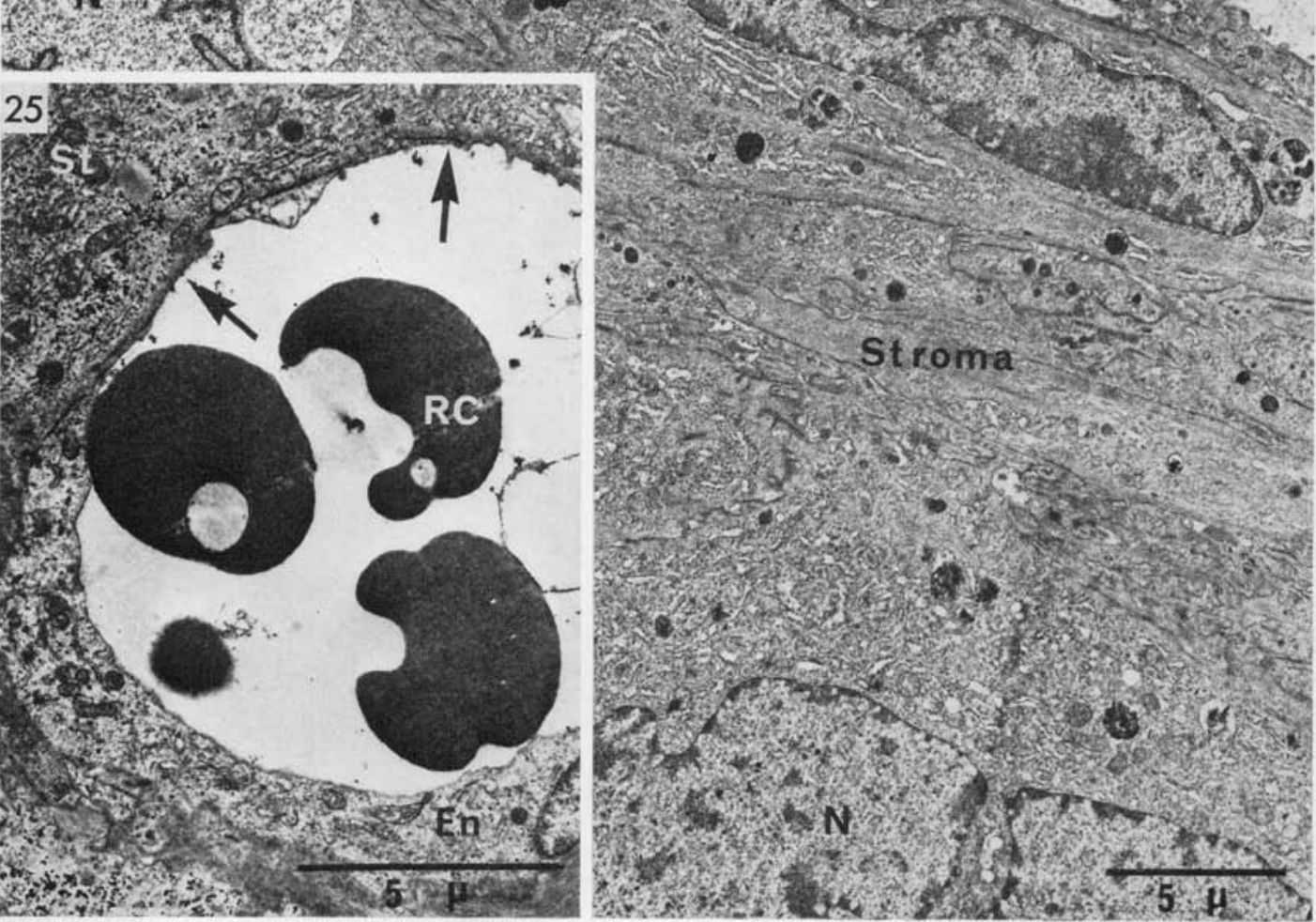
PLATE 15

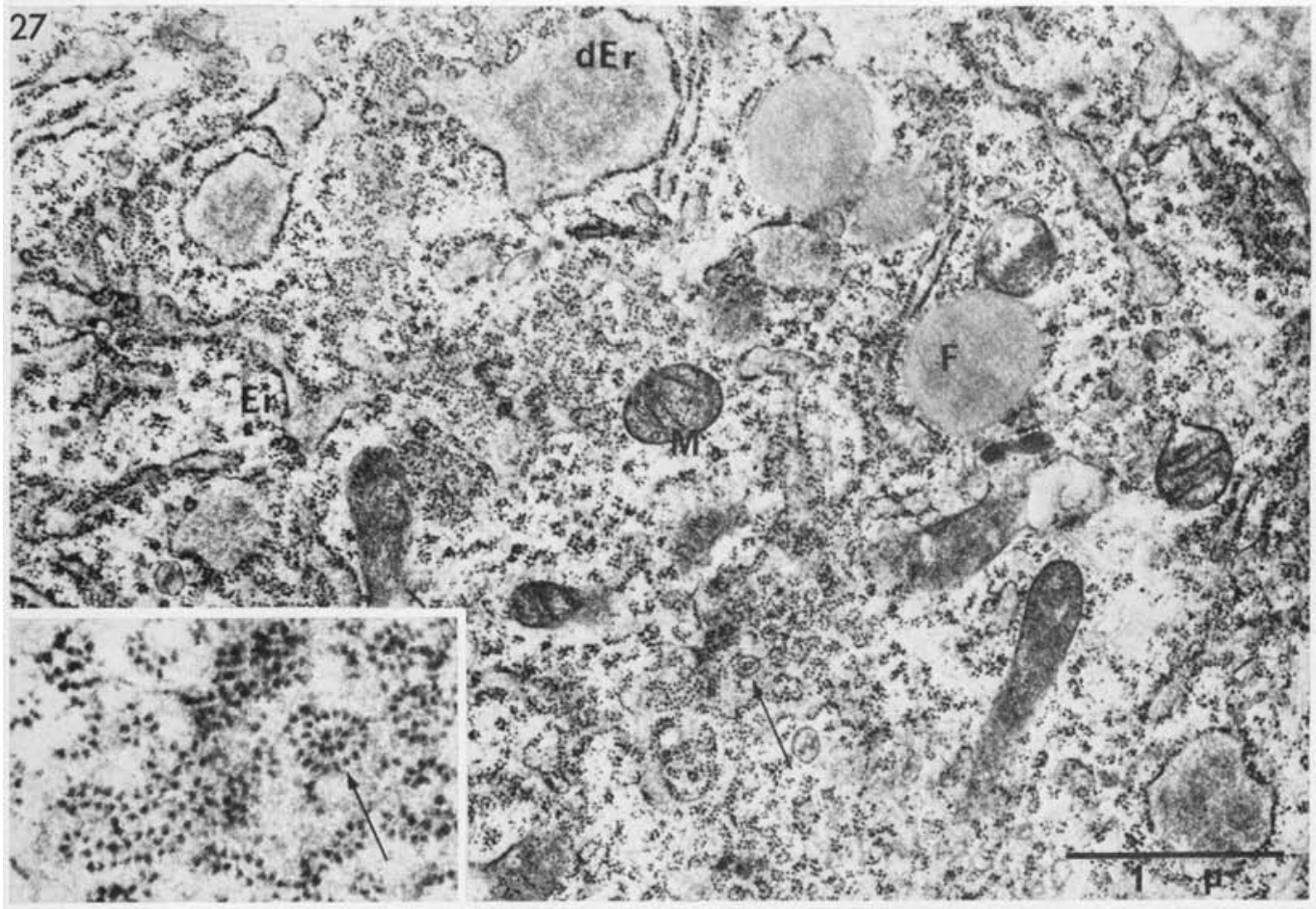

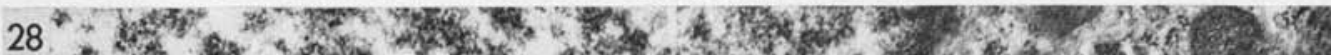

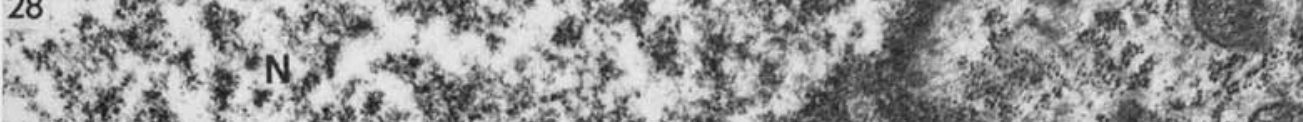

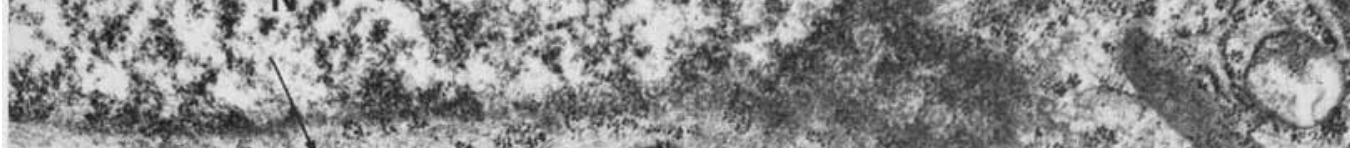

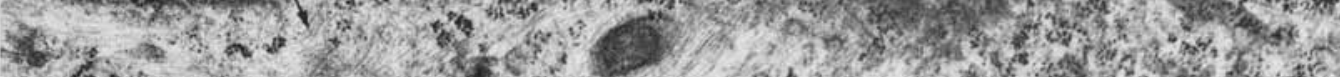

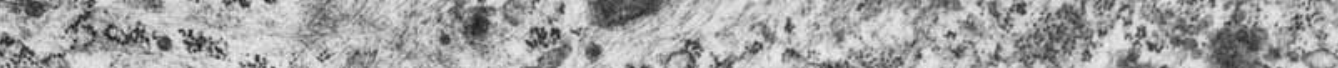

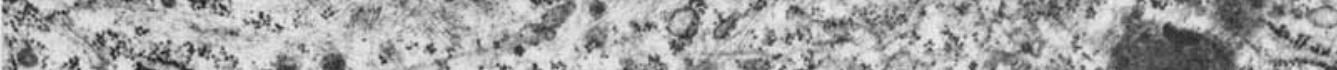

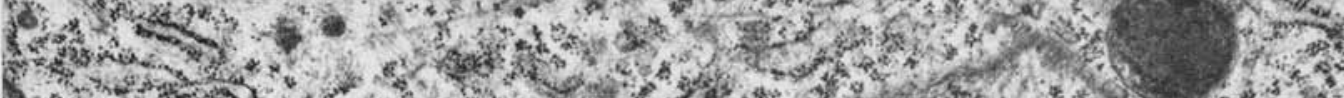

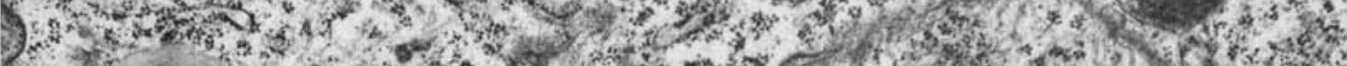

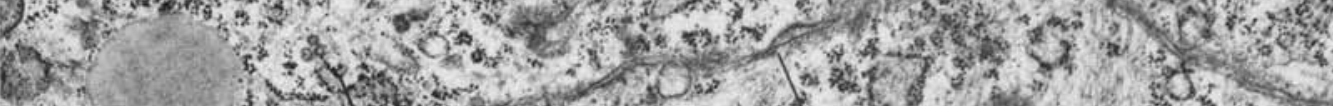

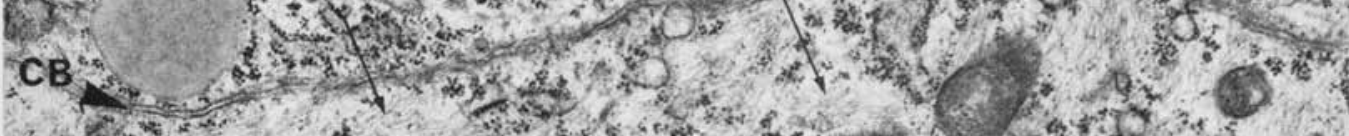

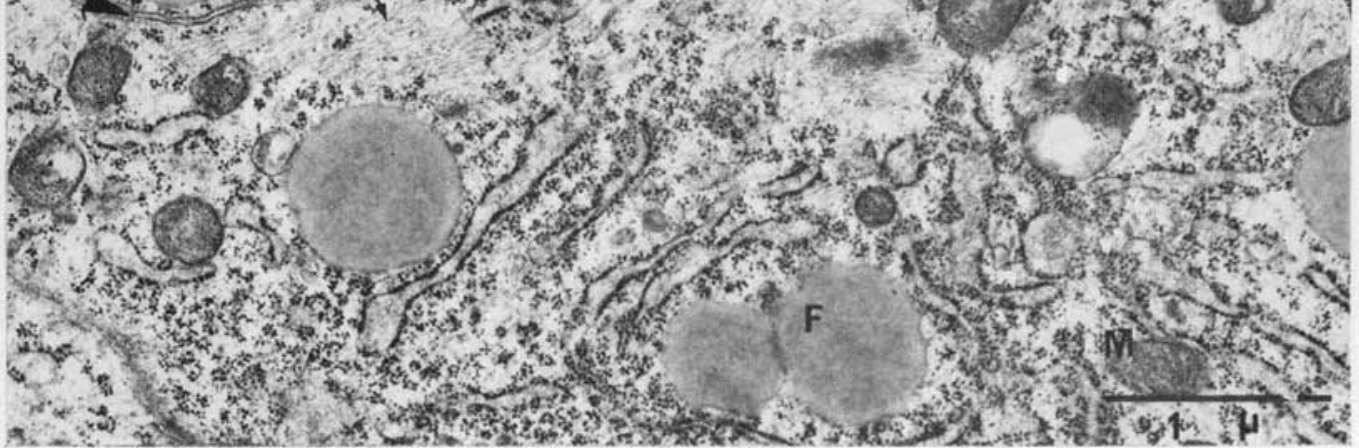


PI. ITE 16

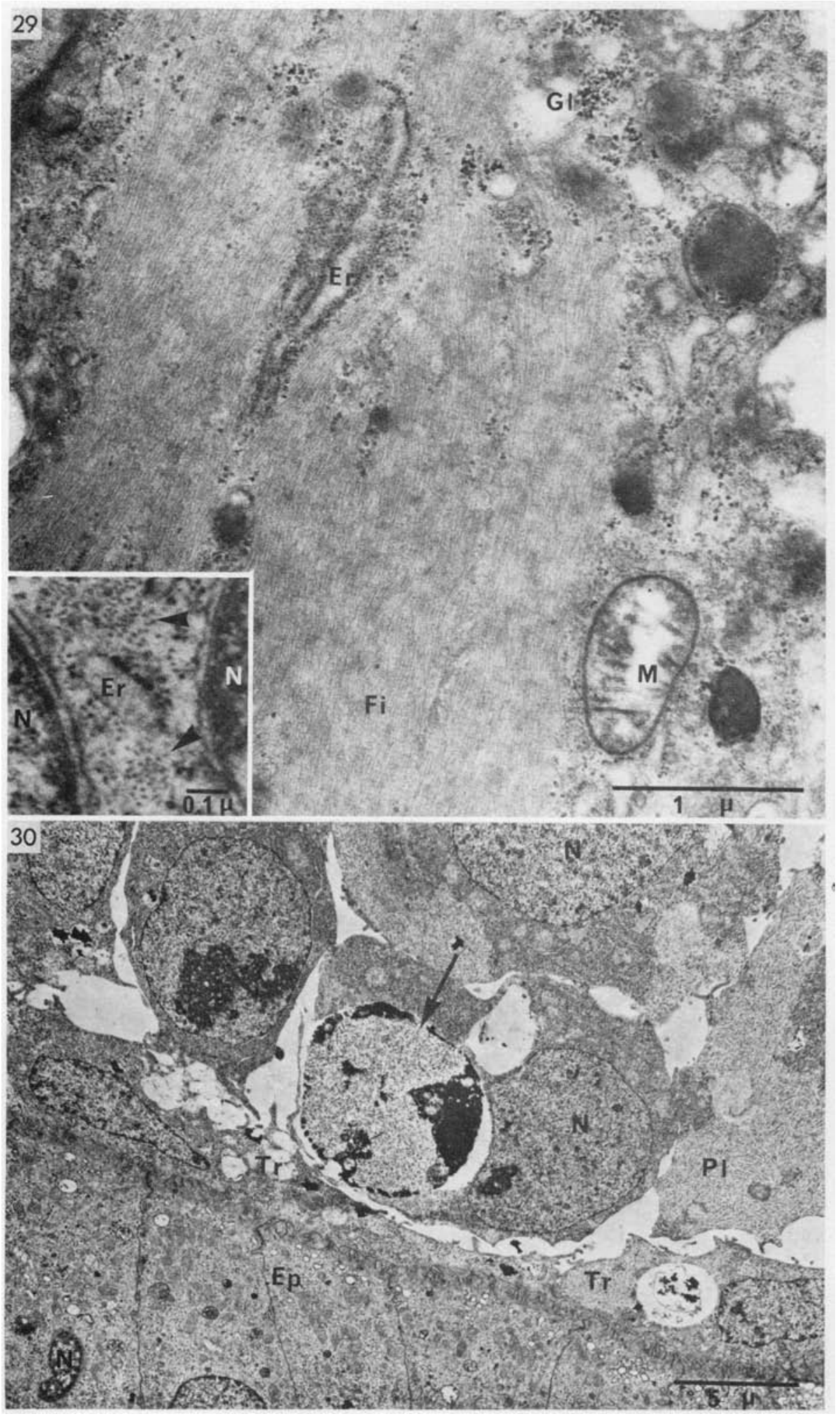


Fig. 3(a). Trophoblast cells on Day 5 p.c. at 20.00 hours attached to a bleb-like protrusion (arrow) of an epithelial cell. Ep, uterine epithelial cell; Tr, trophoblast cell; thick arrow, tight junction.

Fig. 3(b). Early attachment stage. Day 5 p.c. at 14.00 hours. The degree of attachment in this specimen is more advanced than that shown in Pl. 2, Fig. 2. The apices of the epithelial cells are dome shaped. The trophoblast cells are filled with plaques. Thick arrow, tight junction. Ep, uterine epithelial cells; F, fat droplet; $M$, mitochondria; N, nuclei; Pl, plaques; Troph, trophoblast cells.

\section{PLATE 2}

Fig. 2. Survey picture of attachment site on Day 5 p.c., 24.00 hours. Note the striking correspondence of the contours of trophoblast and epithelial cell surfaces. Bleb-like cytoplasmic protrusions of epithelial cells are seen attached to the trophoblast cells (cf. Pl. 1, Fig. 3a). A large portion of the blastocyst cells is occupied by plaques which give the çells a translucent appearance. A leucocyte (arrow) is seen in the epithelial layer. The nuclei of stromal cells are large and round. Bp, bleb-like cytoplasmic protrusion; I.c.m. cell, cells of inner cell mass; Troph. cell, trophoblast cells; U. Epithelium, uterine epithelial cells.

\section{PLATE 3}

Fig. 4(a), (b), (c). Patches of bristle-coated membrane (arrow) on trophoblast cells. Microvilli of the epithelial cells often evaginate the trophoblastic cell membrane (c). Day 5 p.c. at 14.00 hours (a, b) and at 24.00 hours (c). M, mitochondria; Mv, epithelial microvilli; $\mathrm{N}$, nuclei; $\mathrm{Tr}$, trophoblast cells.

FIG. 5. Changes of the luminal epithelial surfaces during late attachment stage (Day 5 p.c., 22.00 hours). The microvilli of the epithelial cells have been replaced by broader cytoplasmic protrusions (arrows) deeply interlocked with the trophoblast cells. Clear vesicles are abundantly seen in the apical region of the epithelial cells. G, Golgi apparatus; Gl, glycogen; Tr.N., nucleus of trophoblast cell; U.Ep, uterine epithelial cell; V, clear vesicles.

Frg. 6(a), (b). Goated vesicles communicating with vacuoles in epithelial cells on Day 5 of pregnancy at 24.00 hours (a) and at 16.00 hours (b). V, vacuoles.

\section{PLATE 4}

Fig. 7. Darkly stained body (arrow) at the attachment site. Day 6 p.c., 24.00 hours. N, nuclei; St, stromal cell; Troph, trophoblast cell; U.Ep., uterine epithelial cells.

Fig. 8. Degenerated uterine epithelial cells at the attachment site on Day 5 p.c. at 22.00 hours. Three adjoining cells are stained darkly and have shrunken mitochondria devoid of well-defined cristae. G, Golgi apparatus; Mb, multivesicular bodies; N, nuclei; Troph, trophoblast cells; V, clear vesicles.

\section{PLATE 5}

Fig. 9. Survey picture of an invasion site on Day 7 p.c. at 11.00 hours. Most of the uterine epithelial cells have been eliminated, but the basement membrane is still intact. At the upper right of the picture, epithelial cells are being engulfed by trophoblastic cells. The proximal endoderm is clearly demarcated off the embryonic ectoderm (thick arrow), and distal endodermal cells are recognized. Plaques have disappeared from the embryonic cells. Within the stromal cells the endoplasmic reticulum forms conspicuous arrays (PI. 13, Fig. 24). The more transparent areas of the stromal cytoplasm (arrows) are packed with fibrillar material (cf. Pl. 14, Fig. 26 and Pl. 16, Fig. 29). Er, arrays of rough surfaced endoplasmic reticulum; Ep. cells, epithelial cells; L, lacunae; $R$, location of early Reichert's membrane.

Fig. 10. Early stage of trophoblastic invasion. Day 6 p.c., 24.00 hours. A trophoblast cell insinuates itself between the epithelial cells and reaches the basement membrane. Free clustered ribosomes crowd the trophoblastic cytoplasm. Many large inclusion bodies are seen in the trophoblast cells. A darkly stained cell (arrow) is surrounded by trophoblastic cells. The epithelial cells contain numerous large fat droplets. Under the basement membrane, bundles of collagen fibres can be seen. BM, basement membrane; Coll, collagen fibres; Ep, epithelium; F, fat droplets; Fl, flocculent material: N, nucleus; Tr, trophoblast. 
PLATE 6

Frg. 11. Penetration of uterine epithelium by abembryonic trophoblast cell on Day 7 p.c. at 11.00 hours. The trophoblast cell is wedged between the epithelial cells and their basement membrane. The basement membrane is much ruffled, but its continuity is still preserved. In a stromal cell, a longitudinal section of a solitary cilium is seen. BM, basement membrane; $\mathrm{Ci}$, solitary cilium; $\mathrm{Ep}$, uterine epithelial cell; F, fat droplets; $\mathrm{N}$, nuclei; $\operatorname{Tr}$, trophoblast cell.

FIG. 12(a). Trophoblast (top)-epithelial (bottom) junction at high magnification. Tight junctions (arrow) are occasionally observed. (Day 6 p.c. at 24.00 hours).

FIG. 12(b). Trophoblast (top)-stromal (bottom) junction at high magnification (Day/8 p.c. at 14.00 hours). The distance between the two unit membranes is in the range of 100 to $200 \mathrm{~A}$. Ep. epithelial cells; St, stromal cells; Tr, trophoblast cells.

\section{PLATE 7}

FIG. 13. Phagocytized epithelial cell (Day 7 p.c. at 11.00 hours). BM, basement membrane; Ep, epithelial cell; Er, endoplasmic reticulum; F, fat droplets; Ly, lysosome; M, mitochondria; R, Reichert's membrane; Tr, trophoblast cell.

Fig. 14. Another part of cell shown in Pl. 8, Fig. 15. A second epithelial cell is being digested within the trophoblast cell. BM, basement membrane; Ep, uterine epithelial cell; $\mathrm{F}$, fat droplets; N, nuclei; R, Reichert's membrane; Tr, trophoblast cell.

\section{PLATE 8}

FIG. 15(a). Diapedesis of red blood cells in the region below the primary decidual zone. Fig. 15(a) shows a red cell escaping from the capillary into the extra-cellular space of the stroma. The basement membrane of the capillary is not recognizable, suggesting an inflammatory reaction. Another red cell is seen lying in a stromal cell (arrow). (Day 6 of pregnancy at 24.00 hours). Cap, capillary lumen; En, endothelial cells; RC, red blood cells; St, stromal cells.

Fig. 15(b). A red cell phagocytized by a binucleated decidual cell (Day 6 of pregnancy, midnight). Between the two nuclei, two cilia (arrow) are seen in a pocket formed by the cell membrane. Note oedematous distension of the extracellular spaces. N, nuclei; RC, red cell.

\section{PLATE 9}

Fig. 16. Blastocyst expansion (Day 5 p.c., 22.00 hours). The trophoblast cells are stretched out to such a degree that the portions indicated by the arrows measure only 0.2 to $0.3 \mu$ across. Ep, epithelial cells; G, Golgi apparatus; Mb, multivesicular bodies; $\mathrm{N}$, nuclei; TJ, tight junction; $\mathrm{Tr}$, trophoblast cells; $\mathrm{V}$, clear vacuoles.

Fig. 17(a). Supernumerary sperm tail found in a trophoblast during early attachment stage. The picture represents part of the blastocyst shown in Pl. 2, Fig. 2 (Day 5 p.c., 24.00 hours). Ep, epithelial cells; Sp, sperm tail; Tr, trophoblast cell.

Fig. 17(b to d). Serial sections of sperm tail embedded in embryonic cell mass of an implanting blastocyst (Day 5 p.c., 24.00 hours). The sperm tail is being phagocytized by one of the embryonic cells (arrow). N, nucleus; Sp, sperm tail.

\section{PLATE 10}

Fic. 18(a to b). Areas filled with plaques and patches of resorbing plaques (broad arrow) in trophoblast cells on Day 6 p.c. at 12.00 hours. The area indicated by a thin arrow is enlarged in Fig. 18(b), which represents a tangential section of plaques showing lattice-like appearance. The repeating intervals of the lattice are about $400 \AA . \mathrm{Ep}$, epithelial cell; $M$, mitochondria; Tr, trophoblast cell.

Fig. 19. Portion of inner cell mass of blastocyst during late attachment stage (Day 6 p.c., 12.00 hours). Plaques still persist in cells near the embryonic pole. Further towards the blastocoele the cells have lost the plaques, and their cytoplasm is crowded with free clustered ribosomes. The innermost layer of cells, probably representing differentiating endoderm, shows widely dilated rough-surfaced endoplasmic reticulum. Bc, blastocoele; End, Endodermal cells; dEr, dilated rough surfaced endoplasmic reticulum; $\mathbf{E r}$, roughsurfaced endoplasmic reticulum; Gl, glycogen-like granules; N, nucleus; Pl, plaques. 
PLATE 11

Frg. 20. Origin of Reichert's membrane. Junction of inner cell mass and trophoblast on Day 6 p.c., 12.00 hours. A streak of material (arrow), believed to represent the nascent Reichert's membrane, extends from an endodermal cell to the inner surface of trophoblast cells. Attached to it are glycogen-like granules. Bc, blastocoele; Ep, epithelial cells; N, nucleus; Pl, plaques; Tr, trophoblast cells; V, clear vacuoles.

Fig. 21. Reichert's membrane in a delayed blastocyst (Day 10 p.c., after ovariectomy on Day 4 p.c. and progesterone treatment). The zona has been shed. The lamellated Reichert's membrane lies between the trophoblast and endoderm, but some sections (arrows) of membrane are related to endodermal cells only. dEr, dilated rough-surfaced endoplasmic reticulum; End, endodermal cells; Er, endoplasmic reticulum; N, nuclei; $\mathbf{R}$, Reichert's membrane; Troph, trophoblast cell.

\section{PLATE 12}

Fig. 22 (a to e). Development of Reichert's membrane. (a) the inner surface of the trophoblast cell is bare. Microvilli are protruding into the blastocoele (Day 5 p.c., 24.00 hours). (b) Day 6 p.c. at 12.00 hours and (c) Day 6 p.c. at 24.00 hours. A thin layer of amorphous, mildly electron-dense material appears on the inner surface of the trophoblast cells, and becomes progressively more condensed. Granules are adherent to this layer. These are probably dislocated glycogen granules rather than secretory products. (d) Day 7 p.c., 12.00 hours. The substance covering the inner surface of trophoblast cells stains more darkly and now resembles a basement membrane. A distal endodermal cell lies adjacent to the trophoblast cell. (e) Day 8 p.c., 14.00 hours. The well-developed Reichert's membrane presents a multi-layered structure. Note the remarkable increase in thickness taking place within about $24 \mathrm{hr}$. Ep, epithelial cell; $\mathrm{M}$, mitochondria; $\mathrm{N}$, nucleus; Tr, trophoblast cell.

\section{PLATE 13}

FIG. 23. Sub-epithelial stromal cells beneath an carly attachment site (Day 5 p.c., 16.00 hours). Note rounded and smooth outline of nuclei, and prominent nucleoli. The roughsurfaced endoplasmic reticulum is more distended. Arrow points at a well developed cisterna which is continuous with the nuclear membrane. BM, basement membrane; $G$, Golgi apparatus; N, nucleus; U.Ep, uterine epithelial cell.

Fig. 24. Decidual cell after established nidation (Day 6 p.c., 24.00 hours). Large nucleoli are often in contact with the nuclear membrane. The chromatin is more condensed and partly marginated. Rough-surfaced endoplasmic reticulum is abundant and forms arrays (arrows). Golgi apparatus is prominent. Bundles of fibrillar material and agglomerations of glycogen granules are commonly found in the cytoplasm. F, fat droplets; Fi, fibrils; G, Golgi apparatus; Gl, glycogen granules.

\section{PLATE 14}

Frg. 25. Capillary near the nidus on Day 6 p.c., 24.00 hours. Part of the capillary lumen lacks an endothelial lining (arrows), and is in direct contact with stromal cells. Microvilli protrude from the stromal cell surface. En, endothelial cell; RC, red blood cells; St, stromal cells.

Fig. 26. Stromal cell during advanced stage of invasion (Day 8 p.c., 14.00 hours). The uterine epithelium has disappeared, and trophoblast cells now appear to be in direct contact with stromal cells. The stromal nuclei are irregular in shape, and marginal condensation of chromatin is still more pronounced (cf. Pl. 13, Figs. 23, 24), particularly near the attachment site. Fibrillar material occupies large areas of the cytoplasm. Fi, fibrillar material; N, nuclei; R, Reichert's membrane; Troph, trophoblast cells.

\section{PLATE 15}

Frg. 27. Polyribosomes in sub-epithelial stromal cells near attachment site on Day 5 p.c., 22.00 hours. Large numbers of coil- or U-shaped polyribosomes are present. These are generally seen on a background staining darker than the surrounding cytoplasm, suggesting that they may be attached to membrane of the endoplasmic reticulum cut tangentially. Arrow (inset) points at polyribosome containing twenty-eight ribosomes arranged in a spiral. Scattered in the cytoplasm are grossly distended cisternae of rough-surfaced endoplasmic reticulum. dEr, dilated rough-surfaced endoplasmic reticulum; F, fat droplets; Er, rough-surfaced endoplasmic reticulum; $M$, mitochondrion.

FIG. 28. Sub-epithelial stromal cells on Day 5 p.c. 22.00 hours, showing fibrillar material (arrows). Bundles of microfils are seen both in the perinuclear region and in the periphery of the cytoplasm. $\mathrm{CB}$, cell boundary; $\mathrm{F}$, fat droplets; $M$, mitochondria; $N$, nucleus. 


\section{PLATE 16}

FIg. 29. Fibrillar material in decidual cells on Day 7 p.c. at 11.00 hours. Parallel bundles of fibrils now occupy much of the cytoplasm. Inset shows the fibrils (arrows) in crosssection. Er, rough-surfaced endoplasmic reticulum; Fi, fibrils; Gl, glycogen granules; M, mitochondria; $\mathrm{N}$, nuclei.

FIG. 30. Unidentified inclusion in cell of inner cell mass on Day 5 p.c., 24.00 hours. Darkly stained material (arrow) forms signet-ring shape. Ep, epithelial cells; N, nuclei; Pl, plaques; $\mathbf{T r}$, trophoblast cells. 